Article

\title{
Environmental Innovation, Open Innovation Dynamics and Competitive Advantage of Medium and Large-Sized Firms
}

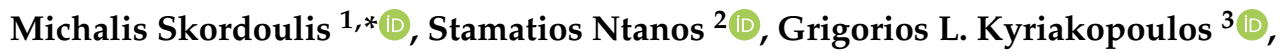 \\ Garyfallos Arabatzis ${ }^{1}$, Spyros Galatsidas ${ }^{1}(\mathbb{D})$ and Miltiadis Chalikias ${ }^{4}$ \\ 1 Department of Forestry and Management of the Environment and Natural Resources, Democritus University \\ of Thrace, 68200 Orestiada, Greece; garamp@fmenr.duth.gr (G.A.); sgalatsi@fmenr.duth.gr (S.G.) \\ 2 Department of Business Administration, University of West Attica, 12244 Egaleo, Greece; sdanos@uniwa.gr \\ 3 School of Electrical and Computer Engineering, National Technical University of Athens, \\ 15780 Zografou, Greece; gregkyr@chemeng.ntua.gr \\ 4 Department of Accounting and Finance, University of West Attica, 12244 Egaleo, Greece; \\ mchalikias@hotmail.com \\ * Correspondence: mskordoulis@gmail.com or mskordou@fmenr.duth.gr
}

Received: 25 November 2020; Accepted: 15 December 2020; Published: 17 December 2020

\begin{abstract}
The present research investigates the contribution of environmental innovation to firms' competitive advantage through the case of medium and large-sized firms operating in Greece. Due to the growing trend of environmental innovation in Greece and a consequent increase in the research interest, this paper fills the existing gap in the relevant literature as there is not enough evidence concerning Greek firms' environmental innovation practices. To meet the research goal, a questionnaire was distributed to 892 medium and large-sized firms operating in Greece; 225 questionnaires were finally responded. The data is based on firms' self-assessment concerning environmental innovation and competitive advantage and are analyzed using both descriptive and inductive statistics, including principal components analysis and multiple linear regression. The research results show that the examined firms implement environmental innovation practices at a moderate level. The most common practices of environmental innovation are the implementation of ISO 14001 management systems and the toxic substances usage reduction. The percentage of ISO 14001 implementation is increased compared to the previous years. Furthermore, the regression analysis revealed that the components concerning environmental process innovation and environmental product innovation have a positive impact on the examined firms' competitive capability. The relationship between open innovation and environmental innovation and the contribution of open innovation dynamics are discussed as well.
\end{abstract}

Keywords: environmental innovation; green innovation; open innovation; green entrepreneurship; firm performance; environmental performance; competitive advantage

\section{Introduction}

During the last decades, the implications of the intense economic development on environmental degradation are becoming more evident, while, at the same time, the concerns over climate change are proliferating [1,2]. Thus, firms worldwide face constant pressures to improve their interaction with the natural environment and take actions to protect it. Such pressures come from governmental organizations through regulations and public policies, from non-governmental organizations through their actions and from consumers through their needs, as there is strong evidence that new consumers' generations are environmentally sensitive [3-5]. 
Environmental innovation is a crucial factor in sustainability for firms and countries [1,6]. New products innovation can focus on delivering environmental benefits. These environmental benefits may include energy savings, $\mathrm{CO}_{2}$ emissions decreasing, water savings, recycling improvements and reduction in environmental pollution [6]. Moreover, environmental product innovation is considered to positively affect firms' productivity and finances [6]. The same relationship is found between environmental process innovation and firms' competitive capability as well [6]. In a quantitative valuation, it is claimed that environmental innovation has a more substantial effect on competitive capability than solely on financial performance [6]. Furthermore, environmental innovation can reduce environmental damage, improve products and services quality and price and create new jobs as well $[6,7]$.

Based on the relevant literature, environmental innovation is also referred as green innovation or eco-innovation and constitutes "all the new or modified processes, techniques, systems, and products to avoid or reduce environmental harm" [8]. Concerning the relationship between environmental innovation and performance, two significant types of performance are identified in the relevant literature: environmental performance and financial performance [7]. Despite the positive relationship of environmental innovation with firms' environmental performance [9], there are ambiguous results concerning its relationship with firms' financial performance [10]. More specifically, neoclassical theories claim that environmental protection just crowds out productive investments $[11,12]$, while, according to other authors, there is evidence that environmental innovation leads to a cleaner environment and, at the same time, leaves room for improvements in firms' financial performance $[9,13]$.

On the one hand, the efficient use of materials is leading to lower costs, differentiated products and waste conversion into saleable products [12]. On the other hand, emissions-cutting is leading to reduced compliance costs and improved reputation. Those factors of efficiency in materials and emissions reduction relate to environmental innovation, to improved financial performance and to the establishment of a competitive advantage [12]. Thus, environmentally innovative firms can improve their financial performance compared to the non-environmentally innovative ones using two complementary methods. Firstly, firms that implement environmental innovation can improve their reputation. Secondly, environmentally innovative firms are constantly seeking for innovations in management processes in order to improve their environmental performance and financial performance [14].

As far as Greek firms are concerned, their awareness on issues related to the environment became more intense after the adoption of the European Union's legislation [15]. According to the literature, we see that during the previous years, environmental innovation practices were not integrated into Greek firms' operation at a high level $[16,17]$. This is explained by the low levels of environmental management systems implementation in Greek firms compared to other EU's countries, as the country is a latecomer in the environmental protection field $[18,19]$. Firms operating in industrial goods and constructions, food and drinks, and health products and services industries appear to be more environmentally innovative [16].

However, despite the low level of environmental innovation of the previous years, there is a growing interest in studying the case of Greece during the last few years [19-23]. This is adequately explained by the fact that during the previous decades the reconciliation between economic growth and environmental protection was very difficult for Greek firms due to the country's existing development patterns [24,25]. These patterns are now changing due to the country's obligation to promote an environmentally sustainable way of development $[15,26]$, the society's increasing environmental awareness [3,5] and the restructuring of the economy after a vicious recession, a process which motivates innovation [27]. Based on the data provided by the European Commission [28], Greece now performs well concerning environmental innovation outputs. At the same time, the increasing interest in environmental innovation is confirmed by both the fact that environmental innovation publications are higher than the EU average (measured in publications per million population) and the fact that Greece is a leader in the interest of the media in environmental innovation [28]. 
Furthermore, the indexes concerning resource efficiency are continually increasing and getting closer to the EU average [28]. The same trend is recorded for the country's eco-innovation index as well [29]. However, there is still much work to be done as in 2017, 18\% of the firms operating in Greece implemented sustainable products while, at the same time, the EU average was $25 \%$. Moreover, 1415 firms were ISO 14001 certified (132 firms per million population), a number which is lower than the EU average [28].

Due to the growing trend of environmental innovation in Greece, the research interest is growing as well. The existing literature confirms the existence of a positive relationship between environmental innovation and Greek firms' performance [30]. At the same time, Greek firms' managers state that they already follow international practices on how to implement environmental protection methods and benefit from them [22]. Thus, Greece can be considered as a good case study in the way for a better understanding of the adaptation of environmental innovation to the EU environment. The purpose of this research is to analyze the implementation of environmental innovation practices in medium and large-sized Greek firms and its contribution to the establishment of competitive advantage. The current research fills a gap in the existing literature providing new evidence for the case of Greece. The examination of this case acquires more interest in recent years, due to the change in the country's economic development where environmental innovation seems to be integrated increasingly. The first section of the paper contains an introduction to environmental innovation and sets out the importance of the case of Greece. In the second section, both the literature review on environmental innovation and its contribution to competitive advantage and the paper's research framework are included. The third section includes the research methodology. The fourth and the fifth section include the research results and their discussion. In this section, the role of open innovation is discussed as well. Last, the sixth section contains the conclusions and limitations of the research.

\section{Theoretical Framework}

\subsection{Environmental Innovation, Open Innovation and Environmentally Innovative Firms}

According to the Eco-Innovation Observatory, environmental innovation is defined as: "the introduction of any new or significantly improved product or service, process, organizational change or marketing solution that reduces the use of natural resources and decreases the release of harmful substances across a whole life-cycle" [31]. Klemmer et al. [32] determined environmental innovation as a subset of innovations that lead to an improvement of ecological equality. Chen et al. [33] defined environmental innovation as the technologies that are involved in energy-saving, pollution-prevention, waste recycling and green product designs. According to a work of Halila and Rundquist [34] on the market success of environmental innovations, the eco-innovation term is often used to identify those innovations that contribute to a sustainable environment through ecological improvements. Furthermore, according to the study of Ar [6], environmental innovation includes all the measures taken to promote the development of improved or new, processes, products or services, techniques and management systems that contribute in environmental impacts mitigation and specific ecological goals.

Interestingly, environmental innovation is conceptually linked to open innovation, forming the open environmental innovation. Open environmental innovation refers to innovations that use knowledge from both the internal and external environment of the firms, to improve firms' innovation with the support of stakeholders; its aim is to create value for both the society and the environment using the knowledge obtained from various stakeholders. The source of open environmental innovation is the synergy between internal processes and open information, while its implementation mainly refers to investments in technology and research and development (R\&D) [35]. Another relevant conceptualization of this synergy is between the processes of the firms' internal environment and the ideas coming from their external environment. Thus, firms can integrate the knowledge of their external environment in order to provide new products or services that can increase their profits [36]. 
Furthermore, a relationship between environmental innovation, organizational sustainability and circular economies, is identified. This relationship can lead to products or processes that can add value for both the firms and their customers; at the same time, a significant reduction in environmental impacts can be achieved. Moreover, environmental innovation is directed to openness [35]. In the relevant literature it is shown that firms following open innovation are able to recognize the value of external inputs into the process of new product and process development and seek to utilize these inputs internally. In this respect it is important to investigate several types of new product successes as open innovation may have influenced the success in different stages: planning, development, marketing and commercialization [37]. Thus, a dynamic relationship between open innovation and the success of environmental innovation is defined.

Environmentally innovative firms are the firms involved in the process of constant change and development, which results in tangible environmental improvements. The research orientation is currently focused on how environmentally innovative firms can develop environmental innovation and improve their financial performance [14].

A strong motivation for firms to become environmentally innovative is that, according to many managers, environmental innovation is a way of achieving productivity improvement, cost savings and defects reduction [38]. Stakeholders such as governments, communities or customers, are found to motivate firms to adopt environmental innovation practices and, at the same time, influence managers' perceptions on the environment [39]. However, in some cases, managers' perceptions of the environment and the need to protect it are not correlated with firms' environmental innovation $[40,41]$. At the same time, based on their motivational role, governments should consider the allocation of funds for activities aiming for open and environmental innovation [35]. The positive relationship between the stakeholders' influence on firms, the environmental innovation practices and the firms' financial and environmental performance is also supported by Weng et al. [1]. These researchers concluded that environmental innovation practices lead to benefits when implemented in products or processes regardless of the industry type.

The Oslo manual is the product of a joint effort of the Organization for Economic Co-operation and Development and the European Commission, written by and for experts from around 30 countries, collecting and processing data on innovation. In total, two types of innovation are identified in the Oslo manual: product innovations and process innovations [42]. Moreover, Chang [43] identified environmental process and environmental product innovation as well. Further, in the same context, according to the research of Ma et al. [7], there are two types of environmental innovation identified in the literature. The first type concerns new or modified products and is referred to as "green product innovation". The second concerns new or modified production equipment, methods and processes and is referred to as "green process innovation" [7].

Furthermore, the concept of open innovation and its sub-attribute of environmental innovation should be also looked under the prism of corporate governance and how managers take their decisions concerning the application of $R \& D$ and innovation [44]. According to Amore and Bennedsen [45], firms with inefficient corporate government systems are falling back on the application of the environmental innovation concept into their corporate strategy. This is because the lack of effective governance creates drawbacks in fund availability since there is a heavy dependence on external funding.

At the same time, many managers, especially those who are responsible for firms' financial operation, seem to perceive environmental protection as a cost that cannot lead in benefits $[4,46]$. More specifically, some of the barriers for a firm to implement environmental innovation practices concern inadequate knowledge, aversion to risk in capital markets or the lack of governmental support [14]. Moreover, some managers believe that even environmental innovations do not lead to better financial performance. The following perspective stems from the belief that the training, producing and safety costs are increased for firms that develop environmental innovations [14]. Open innovation can lead to the elimination of the drawbacks which derive from the inadequate knowledge. 


\subsection{The Effect of Environmental Innovation on Firms' Competitive Advantage}

During the last 20 years, several researchers have examined the contribution of environmental innovation on the establishment of a competitive advantage. While Porter's hypothesis argued that environmental regulation could improve firms' competitiveness, later research focus was given to regulation-induced and voluntary innovations of environmental sign [10].

Despite the fact that environmental innovations can be new to a firm, it is not needed to be new to the market or industry it operates [10]. Such environmental innovations are capable of increasing resource efficiency and leading in increased profitability $[10,13]$. The positive linkage between environmental innovations and firms' profitability can generally apply to both innovations driven by regulations and innovations driven by voluntary choices. The effect of the Porter's hypothesis in the managerial practice is certainly depending on the type of environmental innovation, being proven more significant for regulation-driven innovation. However, the decision for environmental innovation development is often influenced by certain other factors, such as governmental grants, current or expected customers' needs or agreements for good environmental practice [10]. Governments would also benefit from the stabilization of the operation and protection of the market for technology and the subsequent open innovation. Thus, governments should further deal with inefficiencies by establishing regulations to protect intellectual property rights [47].

An early study by Aragón-Correa revealed a relationship between the natural environment, firms' strategies and competitive advantage [48]. The author suggested that the implementation of environmental proactivity into the corporate strategy can create an area for competitive advantage. The adoption of environmental protection strategies to gain competitive advantage is also supported by Banerjee, et al. [49]. Further, Theyel [50] claimed that firms can improve both their profits and environmental performance by adopting environmental innovative practices.

Chiou et al. examined the effect of environmental innovation on firms' economic performance [51]. They found that environmental management and innovation the most important factors for competitive advantage, as environmental innovation can create a market barrier for other competitors and increase opportunities to enter in new green markets. Thus, environmental innovation is a proactive way for firms to increasingly introduce changes in the market.

Both the environmental product and process innovation may affect firms' competitive capability. More specifically, Liao [52] found that environmental product innovation is positively correlated with the advantage of differentiation. In contrast, environmental process innovation is positively correlated with the advantage of low cost and the advantage of differentiation.

Comparing firms with an environmentally oriented strategy with firms without an environmental oriented strategy Wagner and Schaltegger [53] obtained strong evidence that an environmental oriented strategy is positively correlated with several aspects of firms' competitive capability including market, internally, profitability and risk-related competitiveness.

A more recent study [54] has revealed that even during an economic crisis, environmental innovation can lead firms' competitive capability. Furthermore, the authors found that even in financially turbulent times medium and large-sized firms can integrate environmental innovation into their corporate strategy, a practice that is positively correlated with their competitive capability [54].

According to a review paper, a few environmental actions or a proactive approach for just a short period are not enough [55]. Only a long-term environmental strategy that is persistently implemented by the managers could lead to competitive advantage. According to Dangelico and Pontrandolfo [56] corporate strategies which are rotating around the green entrepreneurship concept such as efficient use of materials, energy, and pollution reduction, can create opportunities for gaining an advantage over the competition. The capability of environmental actions and the capabilities of collaboration are positively correlated with competitive advantage and market performance [56].

From a managerial point of view, environmentally innovative firms can gain a competitive advantage by improving their products and internal processes and reducing their operating costs 
through environmental innovation [57]. These firms can also improve their revenues as they can gain higher external reputation and compliance with the existing regulations than their competitors [57].

From a technical point of view, reducing $\mathrm{CO}_{2}$ emissions is possible only if the energy conversion efficiency is improved, which may also help prerequisite a switch in fuel sources. Therefore, $\mathrm{CO}_{2}$ emissions reduction should be considered as a resource efficiency increasing environmental innovation [10].

A visual presentation of the relationship between environmental innovation and firms' competitive advantage is provided in the framework of the present research which is based on the relevant literature.

\subsection{Factors Affecting Firms' Environmental Innovation and Competitive Advantage}

It is widely believed that competitive firms are not only those with the cheapest inputs or those with the most economies of scale. However, the firms being able to innovate constantly can be competitive as well. The application of environmental innovation can lead to knowledge diffusion to other firms of the same sector. Koo et al. [58] reported that environmental orientation of firms is positively correlated with their economic and environmental performance and point out the importance of coordination for the implementation of environmental strategies. They also found that environmental regulations encourage firms towards environmentally and ecologically responsible methods and practices. Concerning the firm's industry, Wagner and Schaltegger [53] found that an environmentally oriented corporate strategy is positively correlated with environmental and economic performance.

The consequences of climate change are having negative impacts on the macro and microeconomic setting of countries as reported in a recent study of Aldieri and Vinci [59]. The impacts are concentrated in productivity reduction. Those researchers investigated the relationship between climate change and technology diffusion, coming from environmentally active firms to other firms of the same industry. Their results revealed that firms belonging to the same industry could benefit from the environmental innovation due to knowledge spillover, especially in the case of developed regions.

Concerning the impact of industry size, the study of Aragón-Correa et al. [60] about the environmental strategy adoption and performance for the case of small and medium sized enterprises (SMEs) revealed increased economic benefits, at the same level as large firms. Moreover, the capability of SMEs to adopt proactive environmental practices is promoted by quicker communication, the more personal relationships, and the owners' strong vision and devotion. At the same time, environmentally conscious managers of such firms can lead them to environmental innovation [35].

However, the effect of environmental innovation on firms' performance is correlated with the national context in which they operate. More specifically, the stakeholders of firms operating in countries with high levels of regulation, may consider the compliance to environmental regulations more important than environmental innovations. In contrast, in environments with less strict regulations, firms are allowed to be innovative, making it possible for them to gain a sustainable competitive advantage [14].

Moreover, except for the regulations, the relative prices of energy and raw materials are considered as primary drivers for environmental innovation. Indeed, firms operating in sectors with a high use of energy and raw materials are also characterized by a higher level of environmental innovative firms. In many cases, the innovations of these firms are introduced in association with environmental regulations [10].

It is also critical to examine the role of governments as demanding buyers. More specifically it is very possible for government to demand for products and services with a high level of respect for the environment [13]. Furthermore, in many cases, governments may ask for exclusively "proven" green suppliers in competitive bid processes in order to ensure their respect of the environment [13].

Similar to the aforementioned governmental regulatory policies, from the firms' point of view, it is crucial to have a better understanding of how the degree of leveraging and the key technological dimensions of open innovation affects firms' performance. Such dimensions are these of external technology acquisition and external technology exploitation and are associated to each other on their 
complementarity [47]. Furthermore, internal R\&D is considered not only to generate new knowledge, but also to contribute to firms' absorptive capacity, allowing them to access, convert, and use new types of knowledge. Further, it is of utmost importance to find ways under which open innovation affects firm performance under environmental turbulence, which is comprised of technological turbulence and market turbulence. Technological turbulence should strengthen the effect of a firm's external technology acquisition on its performance, while it is interesting to investigate the moderating effect of market turbulence on how open innovation influences firm performance [47].

It is noteworthy that a terminology specification of these open innovation terms determines the firms' operability. More specifically, external technology acquisition concerns the innovative ideas and technological knowledge integration into the firms' innovation systems, supporting their access to external innovative knowledge and internal ideas to complement their business models. Therefore, firms can create value for both the society and their customers and compete in the market with a process that has been termed interchangeably as environmental innovation above. Additionally, external technology exploitation refers to the ideas or technological knowledge flowing out of the firms' innovation systems. In this case, firms are purposively pursuing the commercialization or outward transfer of their technological knowledge to other firms aiming at obtaining financial or non-financial benefits [47].

Furthermore, it should be noted that experience is a particularly significant parameter of open innovation prospected, as verified by the relevant literature. Indeed, in experience-driven firms where innovation processes rely on the technical knowledge, a positive correlation between the level of openness and the innovation performance is recorded [36].

Last, it is found that environmentally conscious consumers and their willingness to pay premium prices for green products or services can lead firms to integrate environmental innovation into their strategy $[3,61,62]$. In general, many firms are currently using innovation to command price premiums for green products and open up new market segments.

Therefore, firms must recognize the following barriers and drivers towards innovation:

- Environment can be considered as a competitive opportunity, not as a waste of financial resources or a deferred threat. Yet many firms are not prepared properly to carry out a strategy of environmental innovation that can lead to notable financial offsets [13].

- The era of open innovation for many firms is still developing. Thus, there is lack of a clear understanding of the mechanisms involved inside and outside of the firms' cooperation with externals-a fact that is core to increase innovativeness [63].

- Among the main drivers of open innovation in firms are those reflecting social and economic changes in the labor market patterns. In these new patterns, professionals do not look for a job for life, but for different careers. Thus, firms must look for new ways to recruit talented professionals [35]. Globalization plays an important role as well. More specifically, as it expands the market prospect to a global level reducing the distance, firms are provided a range of benefits [35].

- On the other hand, among the main barriers of open innovation are that of loss of control, increased managerial and organizational complexity, and consequently, increased costs [35].

\subsection{Research Framework}

The literature review has led to the illustration of the relationship between environmental process and environmental product innovation and competitive advantage. Therefore, the research framework of this study is depicted in Figure 1.

The aim of this study was grounded on the following facts. In the relevant literature, it has been reported that firms can benefit from adequately crafted environmental regulations that are more stringent than those faced by their competitors. By stimulating innovation, strict environmental regulations can enhance competitiveness [13]. On the other hand, the fact that the environment has not been commonly a principal area of corporate or technological emphasis remains critical. 
Knowledge about environmental impacts is still rudimentary in many firms and industries, elevating uncertainty about innovation benefits and necessitating relevant managerial tools to be developed [64]. Among the most important managerial tools is that of understanding why and how open innovation adds value to knowledge-intensive processes, taken into consideration the well investigated outside-in process of open innovation, whereas the inside-out process remains less explored [63].

Further, customers are gradually changing their consumerism behavior from a linear towards a circular economy [65]. In these transitional forms of economy and management, firms can make choices based on how they perceive their competitive situation and the world around them. In this world, regulations can be important factors on the direction of innovation, either for better or for worse [13].

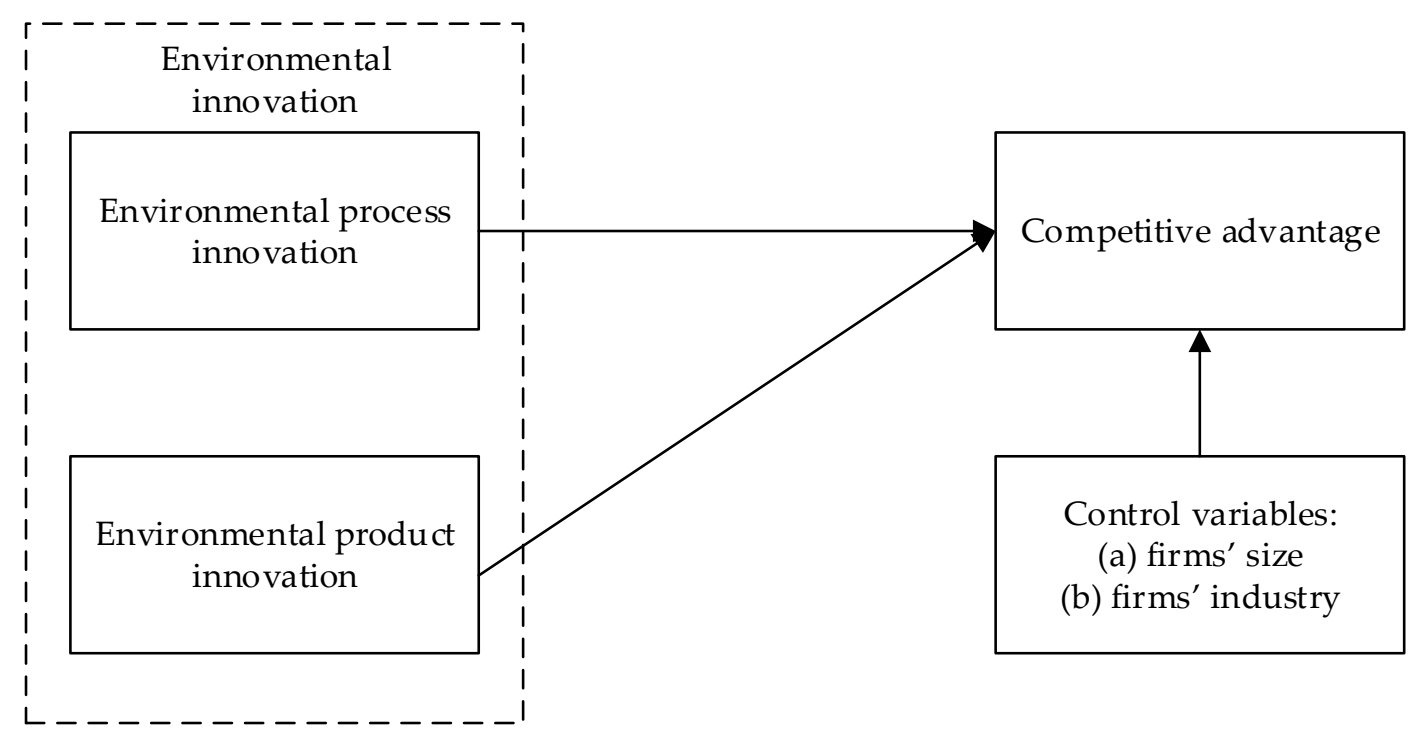

Figure 1. Research framework.

\section{Research Methodology}

\subsection{Materials and Methods}

Based on the research framework, the scope of this study was to examine the relationship between environmental innovation and competitive advantage development. To do so, an empirical study was carried out between 1 December 2019 and 1 May 2020.

Concerning the theory design, the background of the study is linked to product innovation and process innovation offsets. Product offsets occur when environmental regulation produces not just less pollution, but also creates better-performing or higher-quality products, safer products, lower costs of products, products with higher resale or scrap value or lower costs of product disposal. Process offsets occur whenever environmental regulation not only leads to reduced pollution, but also results in higher resource productivity such as higher process yields, less downtime through more careful monitoring and maintenance, materials savings, better utilization of by-products, lower energy consumption during the production process, reduced material storage and handling costs, conversion of waste into valuable forms, reduced waste disposal costs or safer workplace conditions. These offsets are frequently interrelated, therefore achieving one can lead to the realization of several others $[10,13]$.

Concerning the research design, it should be noted that competitive advantage measurement based on firms' environmental strategy is not easy, as there are no data available for individual firms $[54,55,60,66,67]$. Especially concerning the case of Greece, the literature shows that there are not still available many quantitative data $[16,17,30]$. Thus, due to the lack of quantitative data, the research was based on firms' self-assessment as in many other similar cases $[54,55,60,66,67]$. In order to obtain the 
needed data, a 7-point Likert scale questionnaire was developed. The sections of the questionnaire are provided in Table 1. It should be noted that in the questionnaire's fifth section, there were quantitative questions concerning firms' environmental innovation and competitive advantage constructs; however, only a few firms accepted to provide such data, meaning that their inclusion in the statistical analysis would not lead in representative results.

Table 1. Questionnaire structure.

\begin{tabular}{cc}
\hline Questions Number & Questions Description \\
\hline $1-10$ & Environmental process innovation \\
$11-20$ & Environmental product innovation \\
$21-35$ & Competitive advantage \\
$36-40$ & Respondents' socio-demographics \\
$41-47$ & Firms' characteristics \\
\hline
\end{tabular}

Initially, the research population was defined. Since quantitative data collection was not easily accessible, the research population consisted of the most engaged person to the environmental strategy of any of the Greek firms of medium or large size. As far as it is concerned, the research population consisted of the above-mentioned firms' department managers, general managers, CEOs or Board of Director's chairmen.

The definition of medium and large-sized firms was based on the European Union's DirectorateGeneral for Internal Market, Industry, Entrepreneurship and SMEs [68]. Following this definition, the identification of such firms in Greece was based on Hellastat's IMENTOR database [69]. This database includes 1460 firms meeting the criteria of medium and large size.

However, according to other researchers [70], firms belonging to industries with little or no impact on the environment were excluded. Such firms belong to software, real estate brokerage, financial intermediaries and similar industries. This has to do with the fact that firms with higher environmental impact tend to take environmental protection measures more intensively [18]. In any case, we included firms belonging to all the industries with high environmental impact as they are identified by the Eurostat [71]. Based on the above criteria, 323 firms were finally excluded.

More specifically, based on the following Table 2, the industries to which most of the sample's firms belong were foods and drinks $(20.0 \%)$ and industrial goods and constructions $(20.0 \%)$.

Table 2. Examined firms' industries.

\begin{tabular}{cc}
\hline Industry & \% Percent \\
\hline Business to business services & 15.6 \\
Business to customer services & 9.0 \\
Consumer products & 8.9 \\
Energy and water & 4.4 \\
Food and drinks & 20.0 \\
Health products and services & 11.1 \\
Industrial goods and constructions & 20.0 \\
Industrial, chemical products and medicines & 4.4 \\
Tourism, catering, entertainment and information & 4.4 \\
Transport and storage & 2.2 \\
\hline
\end{tabular}

Referring to the examined firms' size, $83 \%$ of them were medium, while $17 \%$ were large-sized. These percentages can be considered representative as $0.9 \%$ of the firms in Greece are medium, while $0.2 \%$ of them are large-sized [28] based on the above-mentioned EU's definition [68]. Thus, concerning solely the medium and large-sized firms in Greece, $81.8 \%$ of them are medium-sized while the remaining $18.2 \%$ are large-sized.

According to Table 3, most of the examined firms operate in the region of Attica (51.4\%). On the contrary, the least operate in the regions of Eastern Macedonia and Thrace (1.2\%) and North Aegean 
(1.2\%). It should be noted that Attica is the wealthiest region of Greece (EUR 110,6 million GDP), while North Aegean is the poorest one (EUR 3,3 million GDP) [72].

Table 3. Examined firms' geographical distribution.

\begin{tabular}{cc}
\hline Industry & \% Percent \\
\hline Attica & 51.4 \\
Central Greece & 3.4 \\
Central Macedonia & 15.6 \\
Crete & 4.4 \\
Eastern Macedonia and Thrace & 1.2 \\
Epirus & 2.4 \\
Ionian Islands & 2.4 \\
North Aegean & 1.2 \\
Peloponnese & 2.4 \\
South Aegean & 2.4 \\
Thessaly & 6.4 \\
West Greece & 4.4 \\
West Macedonia & 2.4 \\
\hline
\end{tabular}

Since the research population consisted of 1137 sample units and the research analyses were carried out at a $5 \%$ level of significance, approximately 225 questionnaires should be responded in order to obtain the appropriate sample size [73]. Following the determination of the research population and the minimum sample size, we created a list including all 1137 firms and assigned each of them a serial number. Then, following similar cases of sampling [3] we randomly selected the firms, using the random number generator of Microsoft Excel-based on the "RANDBETWEEN" function. The randomly selected firms were contacted to take part in the research. For each one of the firms' department manager, general manager, CEO or Board of Directors chairman who did not respond to the research, another firm was selected using the above method. In order to obtain the needed sample size, 892 firms were contacted in total. Thus, the response rate was about $25 \%$. This rate can be considered satisfactory. This rate was obtained due to the fact that we followed up all the participants as proposed by other researchers [74] and the fact we replaced the ones who did not respond in time. Another reason for this rate is that as in similar cases participants are very interested for the research. In similar cases concerning either Greece $[54,74]$ or other countries $[70,75,76]$, the response rate is between $15 \%$ and $35 \%$.

The collected data was analyzed using SPSS V.26, using both descriptive and inductive statistical methods. More specifically, we used descriptive statistics to analyze the environmental process and product innovation practices implemented by the examined firms. A principal components analysis was carried out in order to reduce the number of the variables and compute the components of the predictive model. Furthermore, it was used to confirm that the data fit to the research framework. In order to find possible statistically significant differences between environmental process and environmental product innovation practices related to the control variables, a Mann-Whitney U test was carried out, due to the categorical nature of the variables. The correlation between the extracted components was examined using Pearson's correlation coefficient. Last, a multiple linear regression analysis was carried out in order to identify the predictive model concerning firms' competitive advantage development based on their environmental innovation. Among the many methods used to examine environmental innovation and firms' competitive advantage, regression analysis was used by other researchers as well $[33,50,52,77,78]$.

Based on the data of the following Table 4, we obtain that most of the respondents are males, while $71.1 \%$ of them are between 35 and 55 years old and $57.8 \%$ of them hold a Master's degree. As far as the respondents' position is concerned, most of them $(60.1 \%)$ are department managers, while those of the second most common position is general managers $(22.1 \%)$. 
Furthermore, the mean value concerning respondents' experience in their current position is 9.2 years while the standard deviation of this variable is 8.4 years, showing a wide range between its values.

Table 4. Respondents' socio-demographics.

\begin{tabular}{ccc}
\hline & & \% Percent \\
\hline \multirow{2}{*}{ Gender } & Male & 84.4 \\
& Female & 15.6 \\
\hline \multirow{3}{*}{ Age } & $18-35$ & 11.1 \\
& $35-45$ & 28.9 \\
& $45-55$ & 42.2 \\
Level of education & $55-65$ & 17.8 \\
\hline & Associate's degree & 2.2 \\
& Bachelor's degree & 31.1 \\
& Master's degree & 57.8 \\
& Doctoral degree & 8.9 \\
\hline \multirow{4}{*}{ Position } & Department manager & 60.1 \\
& General manager & 22.1 \\
& CEO & 15.6 \\
& BoD chairman & 2.2 \\
\hline
\end{tabular}

Concerning possible errors in the research, it should be initially noted that due to the fact that the size of the target population was relatively small and a significant proportion of its units were used, there was a low possibility of sampling error. Furthermore, the possibility of selection error was low as we used Hellastat's IMENTOR which is a reliable database and we have used the above-mentioned specific selection criteria; thus, there is a convergence between the target population and the sample. Last, in order to examine the possibility of non-response error, we have used the method of Armstrong and Overton [79] as suggested by other authors as well [54]. Thus, we have tested the existence of statically significant differences between the first and the last 30 questionnaires using the Mann-Whitney $U$ test given the ordinal nature of the variables. Since the test's results did not reveal any statistically significant differences (sig. > 0.05), we concluded that there was no non-response error. That is because the responses of those responded in the end [79] were not found to differ at a statistically significant level with the responses of those responded in the beginning $[47,80]$.

\subsection{Variables' Definition}

\subsubsection{Environmental Innovation}

Environmental innovation can be measured in various ways. Tsai and Liao [81], measured firms' environmental innovation using six quantitative components: materials, energy, $\mathrm{CO}_{2}$, dangerous substances, other pollution and recycling. In their work concerning German firms, Horbach et al. [82], were based on the Community Innovation Surveys (CIS) of the European Commission to find how different factors drive different types of environmental innovation. De Marchi [78] carried out the same analysis concerning the case of Spain. Horbach [83] used the CIS to find determinants of eco-innovation in European countries and compare them.

Since the EU's CIS database does not include data concerning Greece [84], the lack of data concerning individual firms and the fact that only a few firms provided quantitative data in our research, we followed the methods of other researchers $[53-55,60,66,67]$ in order to measure environmental innovation measurement based on the respondents' perceptions, as already mentioned in the research methodology section. Thus, in order to define environmental innovation, we used the body of the relevant literature. As many researchers have identified different types of environmental innovation, 
we used the classification of environmental process and product innovation as proposed by the Oslo Manual [42] and analyzed by Chang [43].

The taxonomy of environmental product and process innovation was finally used in our study as this is very popular concerning both the environmental innovation [43] and the general aspect of innovation [74] among the relevant literature. Based on the items we used to measure environmental process innovation and environmental product innovation, we consider the former as environmentally friendly and innovative firms' operations and the latter as environmentally friendly and innovative products and ways of production.

The items of environmental process innovation and environmental product innovation we have used in our research are already identified by relevant studies $[56,60]$.

\subsubsection{Competitive Advantage}

The ultimate goal of every firm is to gain a sustainable competitive advantage [85]. Despite its fundamental importance, there are many approaches to the concept of competitive advantage, which differ semantically from each other, so that no exact conceptual definition can be found $[86,87]$. However, there are two main trends. The former which considers competitive advantage as the ability of a firm to impose favorable terms on it in trade while the latter, considers it as any cause or factor that leads a firm to higher performance than this of its competitors [88]. These trends show that the competitive advantage is a multifactorial concept, which is inextricably linked to improved performance.

Based on the above analysis, we consider that a firm's competitive advantage determines its position in the market. For this reason, we have used the approach of Wagner and Schaltegger [53]. More specifically, Wagner and Schaltegger have investigated the influence of environmental strategy on the EU's specific industrial sectors firms' competitiveness. The principal components analysis they carried out resulted in the items of environmental competitiveness which we used in our study as well (see Appendix A, Table A1). The main reason for using this approach was that it is difficult to note the influence of environmental innovation in a firm's overall performance [89]. This fact was taken into consideration in the methodology of Wagner and Schaltegger [53] as they focused on the items of firms' performance that can be easier influenced by environmental innovation. Furthermore, the items they used fit well with our approach to competitive advantage. Thus, their definition of environmental competitiveness was suitable to be used in the current research.

\subsubsection{Control Variables}

As already mentioned, competitive advantage depends on many factors. Thus, it became necessary to identify some control variables that could influence the firms' competitive advantage. As proposed by many authors, the firms' industry may influence competitive advantage [53]. Furthermore, according to other researchers, firms' size is a determining factor of competitive advantage [89]. Thus, we used the firms' industry and firms' size as control variables in our analysis.

In order to identify firms' industries, we used the classification proposed by Hellastat [70]. In contrast, in order to identify firms' size, we followed the European Union's Directorate-General for Internal Market, Industry, Entrepreneurship and SMEs [71].

\section{Results}

\subsection{Environmental Innovation Components Definition}

A set of 35 variables are used in order to define environmental process innovation, environmental product innovation and competitive advantage index variables. Initially, a Principal Components Analysis (PCA) is applied. The primary approach of this method is to reduce the variables' dimensionality and compute the components based on the initial set of variables in an optimal way. The main difference of PCA with Explanatory Factor Analysis (EFA) that could have been used as 
well, is that FA measures a factor through the correlations between a set of variables. PCA and EFA can produce similar results; however, PCA provides information such as individual respondents' scores on the components and requires fewer resources than EFA [90]. In the PCA, Kaizer's varimax rotation method is used in order to obtain the best fitting results [5]. The PCA resulted in three components. It is noteworthy that seven of the variables used to define environmental process innovation, environmental product innovation and competitive advantage (see Table 1) had eigenvalues below 1 and were not included in any of the extracted components (see Appendix A, Table A1). These components represent the index variables as mentioned above. The PCA's results confirm that the data fit to our conceptual framework of environmental innovation and competitive advantage and our consistent with the definitions we used (see Appendix A, Table A1). The items number and the Cronbach's alpha values of the extracted components are provided in Table 5.

Table 5. Environmental innovation constructs.

\begin{tabular}{cccc}
\hline Components & Items & $\begin{array}{c}\text { Cumulative Percent of } \\
\text { Total Variance Explained }\end{array}$ & Cronbach's Alpha \\
\hline Environmental process innovation & 6 & 63.12 & 0.824 \\
Environmental product innovation & 9 & 71.48 & 0.836 \\
Competitive advantage & 13 & 76.89 & 0.801 \\
\hline
\end{tabular}

The extracted components explain $76.89 \%$ of the total variance, a proportion which is satisfactory as it is higher than the minimum acceptable which is equal to $60.00 \%$ [91]. Kaiser-Meyer-Olkin's measure of sampling adequacy is equal to 0.86 while Bartlett's test of sphericity (sig. $=0.000)$ rejects the null hypothesis of an identity matrix; these results confirm that the items used are related and suitable for PCA $[5,92]$. Furthermore, the extracted components' Cronbach's alpha values show high internal consistency as they are greater than the lowest acceptable value, which is about 0.7 [93].

\subsection{Firms' Environmental Innovation Analysis}

The examined firms' environmental product and environmental process innovation will be analyzed based on the results of the above-mentioned PCA.

The following Figure 2 provides the environmental process innovation practices of the examined firms. Taking into account the 7-point Likert scale of the variables, most of the firms implement environmental process innovation at a moderate level. The most implemented practice of environmental process innovation is the use of ISO 14001 certifications, while the least implemented one concerns the natural environmental seminars for the firm's executives. A low level of periodic natural environmental audits is recorded as well.

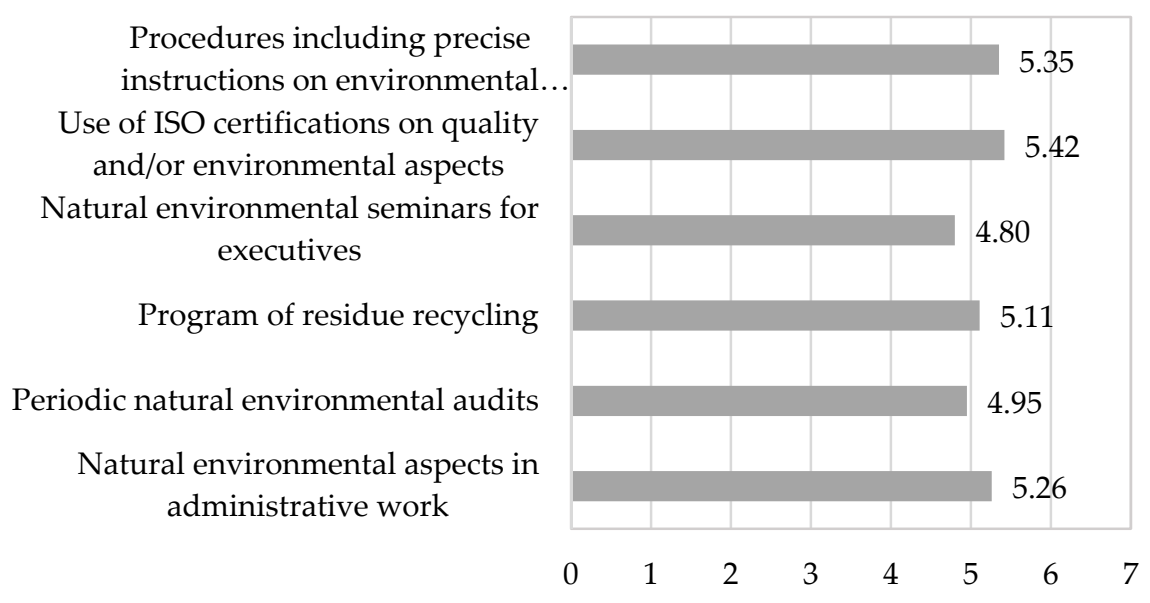

Figure 2. Environmental process innovation. 
Figure 3 provides the data concerning environmental product innovation practices. It can be concluded that, as in the case of environmental process innovation, most of the firms implement environmental product innovation at a moderate level. Toxic substances reduction is the most applied practice of environmental product innovation. On the contrary, even though energy efficiency improvement is the second most implemented practice of environmental product innovation, the usage of energy from renewable energy sources is not very high. This result is in contrast to what is observed in the country, where energy extraction from renewable energy sources is widespread [3]. Last, the practice with the lowest value is this of environmental events sponsorship.

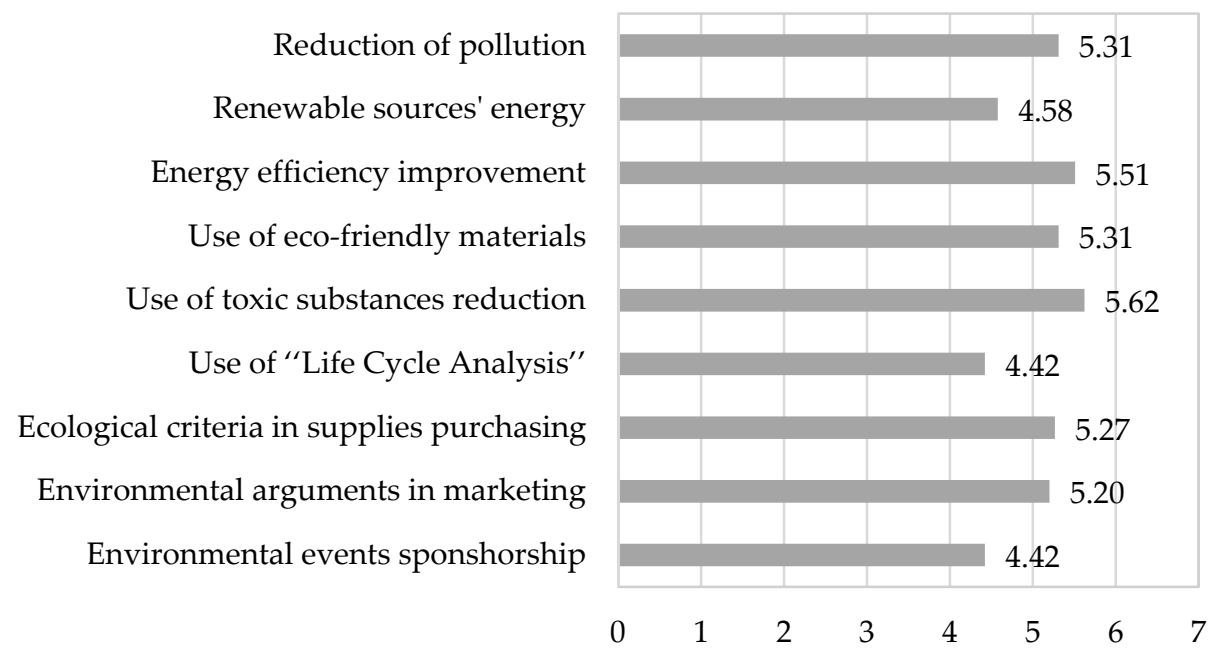

Figure 3. Environmental product innovation.

An important aspect that should be examined is the possible statistically significant difference between environmental innovation practices and the firms' industry. To examine this, a Kruskal-Wallis test is carried out given the categorical nature of the variables. The test results (see Appendix A, Table A2) did not reveal any statistically significant difference except for the use of ISO 14001 certifications (sig. = 0.029). The results of pairwise Mann-Whitney $U$ tests carried out show that there is a statistically significant difference (sig. $=0.001)$ between the mean ranks of industrial, chemical products and medicines (5.80), and business-to-business services (4.00) industries. This is an expected difference as in the industrial, chemical products and medicines industry the level of energy and raw materials usage is very high, while there is a high association with regulations; thus, a higher level of ISO certifications environmental innovations, in general, is supported by the literature [10].

Another factor that would affect firms' environmental innovation is their size, based on the existing literature. However, the results of a Mann-Whitney $U$ test do not reveal any statistically significant difference between medium- and large-sized firms' environmental innovation constructs' mean ranks as shown in Table 6. This result is contradicted in the literature. However, it should be taken into account that our sample consists solely of medium and large-sized firms. In similar cases, the size of a firm is not considered as a control variable concerning its strategy or its performance [80,94]. In most of the cases, size plays a statistically significant role when firms of all the sizes, including SMEs are examined in the sample $[95,96]$.

Table 6. Mann-Whitney U test results.

\begin{tabular}{lccc}
\hline & \multicolumn{2}{c}{ Mean Rank } & \multirow{2}{*}{ Sig. (2-Tailed) } \\
& Medium & Large & \multirow{2}{*}{ (24.63 } \\
\hline Environmental Process Innovation & 19.73 & 0.238 \\
Environmental Product Innovation & 22.87 & 23.27 & 0.923 \\
\hline
\end{tabular}




\subsection{Environmental Innovation and Competitive Advantage}

The next step of the research is to examine the existence of a possible correlation between the defined constructs. Before the correlation analysis, constructs' distribution should be considered. The results of the Kolmogorov-Smirnov test of Table 7, show that all the variables have a good fit in normal distribution; thus, parametric methods are used.

Table 7. One-sample Kolmogorov-Smirnov test.

\begin{tabular}{ccc}
\hline Constructs & Kolmogorov-Smirnov Z & Sig. (2-tailed) \\
\hline Environmental process innovation & 1.094 & 0.782 \\
Environmental product innovation & 0.829 & 0.898 \\
Competitive advantage & 0.726 & 0.868 \\
\hline
\end{tabular}

Data provided in Table 8 confirm the existence of a statistically significant positive correlation between competitive advantage and both environmental process innovation (sig. $=0.001$ ) and environmental product innovation (sig. $=0.006$ ).

Table 8. Environmental innovation constructs' and competitive advantage correlations.

\begin{tabular}{cccc}
\hline & & $\begin{array}{c}\text { Environmental } \\
\text { Process Innovation }\end{array}$ & $\begin{array}{c}\text { Environmental } \\
\text { Product Innovation }\end{array}$ \\
\hline Environmental Process Innovation & $\begin{array}{c}\text { Pearson's R } \\
\text { Sig. }\end{array}$ & & \\
Environmental Product Innovation & $\begin{array}{c}\text { Pearson's R } \\
\text { Sig. }\end{array}$ & 0.018 & \\
& Pearson's R & 0.982 & \\
Competitive Advantage & Sig. & 0.488 & 0.374 \\
& & 0.001 & 0.006 \\
\hline
\end{tabular}

To further examine and verify the above-observed correlations, a multiple linear regression model is applied. In this model, competitive advantage is considered as the dependent variable, the constructs concerning environmental process innovation and environmental product innovation are considered as the predictors, while firms' size and industry are considered as the control variables.

The stepwise method is used to develop the final model. This method allows reconsidering whether any of the variables can be excluded or not. In the first step of the method, a maximum $p$-value for removing a variable ( $p$-valueOUT) and a minimum one ( $p$-valueIN) for entering a variable is set. In the method's second step all Type III partial F-tests for each variable that is not yet adjusted to those already entered in the model is calculated; if a variable's lowest $p$-value is lower than $p$-valueIN, then the variable is entered in the model. In the third step of the method, all the partial F-tests for all the variables are calculated; if a variable's highest $p$-value is higher than $p$-valueOUT then the variable is excluded from the model. The model is readjusted then, and the third step is repeated until no variable can enter in the model. Then, the process goes to the second step and is repeated until no variable can either be entered in the model or be excluded from it [97].

The regression models based on the stepwise method are provided in the following Table 9. More specifically, two regression models are calculated. Based on the above-mentioned analysis of the stepwise method, the second model is the final and the best fitting one.

The final model's equation is the following:

$$
\begin{gathered}
\text { Competitive advantage }=0.488 \times \text { Environmental process innovation }+ \\
+0.378 \times \text { Environmental product innovation }
\end{gathered}
$$

Based on the above equation we see that both the environmental process innovation and the environmental product innovation are associated with the firms' competitive advantage, 
while environmental process innovation is the most important component. Furthermore, firms' size and industry are omitted from the model.

Table 9. Regression models.

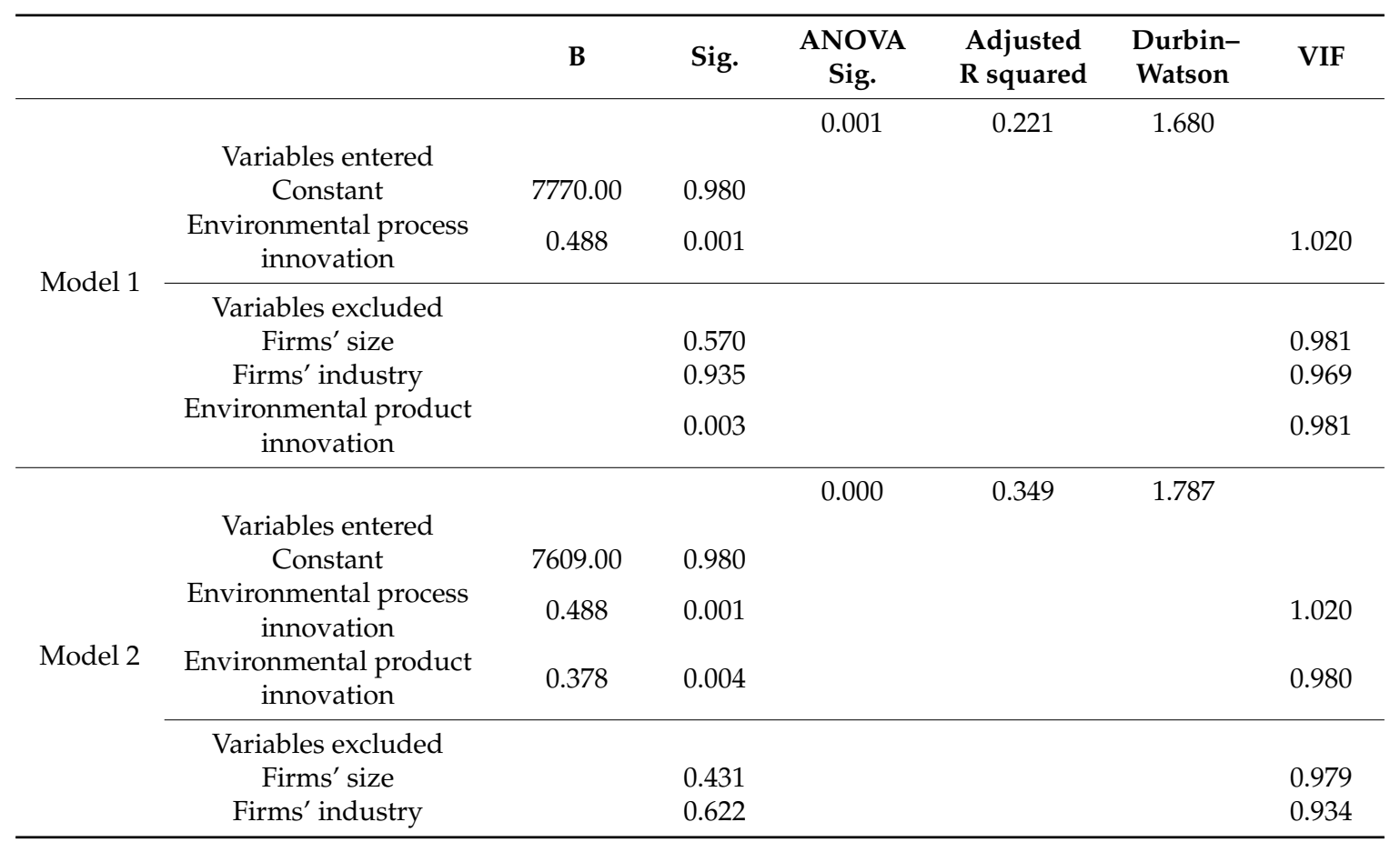

To test the model's validity, we see that Durbin-Watson test's value is equal to 1.787 , meaning independence of observations while, independent variables' variance inflation factor (VIF) does not indicate multicollinearity.

Based on the following Figure 4, we see that regression residuals are normally distributed (Normal P-P Plot), while the data show homoscedasticity (Pearson correlation coefficient sig. $=0.980$ ).

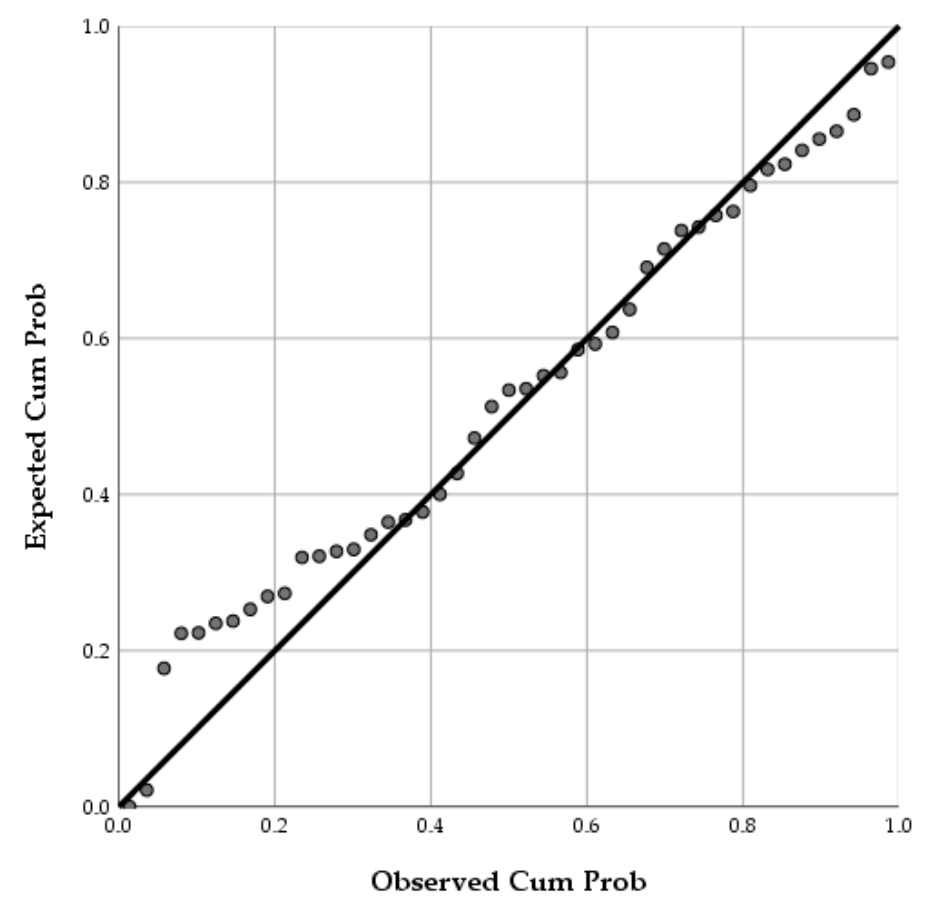

Figure 4. Normal P-P Plot to test the model's residuals distribution. 
The possibility of endogeneity cannot be neglected as well. The issue of endogeneity in a regression model arises when the independent variables are correlated with other variables that are not observed and are part of the error $[98,99]$. In many cases, these variables are difficult to manipulate as they may share common causes with the dependent one [100]. This problem is common in almost any aspect of research in financial [101] and marketing models [98], including cases related to competitive advantage [102]. Following the relevant theory, we have calculated the model's error in order to illustrate the possible existence of endogeneity [103,104]. The scatter plots of Figures 5 and 6 do not indicate a statistically significant linear correlation between the regression error and the independent variables; thus, there is no evidence for endogeneity.

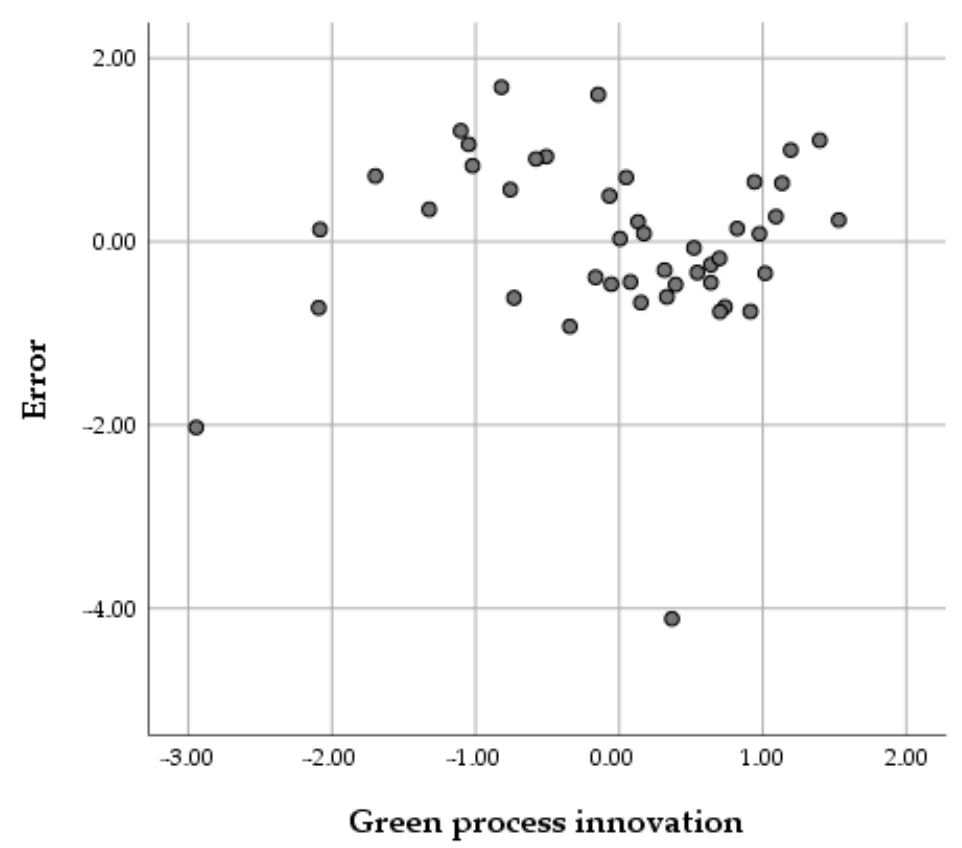

Figure 5. Regression error and green process innovation scatter plot.

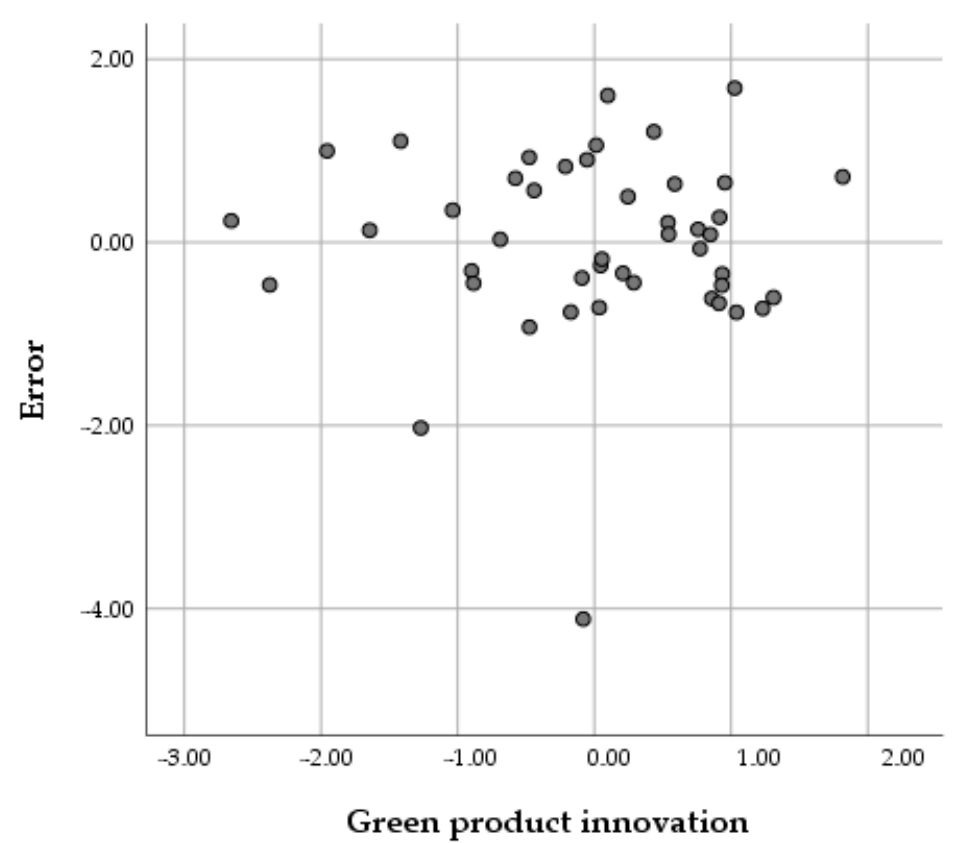

Figure 6. Regression error and green product innovation scatter plot.

Thus, the model's validity is confirmed as the assumptions of linear regression are not violated. 


\section{Discussion: Environmental Process and Product Innovation and Open Innovation}

Examining the regression analysis, we conclude that both the environmental process and product innovation play a significant role in driving a competitive advantage. More specifically, we see that the higher the values of environmental process and product innovation are, the highest the value of the competitive advantage is.

Furthermore, the value of the regression analysis adjusted R squared coefficient is equal to 0.349 , meaning that environmental innovation constructs explain the $34.9 \%$ of the variance of competitive advantage. Although this percentage is rather high, the competitive advantage of a firm also relies on other factors that are omitted from our analysis. Those factors are quite difficult to capture and furthermore they present an inconsistency among different countries and different ownership types. Among such factors of imperative investigation is whether the external technology acquisition can moderate the external technology exploitation impacting on firm performance [47].

The regression analysis results are consistent with the results of many other researchers $[33,48-$ $52,54,56,77]$. Many of these researchers have used regression models $[33,52,77,78]$. Thus, as in many cases of other countries, strong evidence is obtained for a positive correlation between environmental innovation and competitive capability of the medium and large-sized firms operating in Greece. These studies provide no evidence of a problem of a double causal relationship.

Furthermore, according to our analysis, firms' size and industry do not play a statistically significant role in the establishment of a competitive advantage. As in the case of the environmental process and product innovation examined above, this result can be adequately justified by the fact that our sample consists solely of medium and large-sized firms.

More specifically, in our statistical analysis we included the variable of firm size in order to indirectly examine the impact of the ownership concentration. However, this variable was omitted from the final model since its relationship with competitive advantage was not statistically significant for out dataset. This result is compatible to the review study of Asensio-López et al. [44]. In this review study on corporate governance and innovation it was concluded there is not enough evidence to support a relationship between ownership concentration and innovation and future research should be focused on board characteristics (size, composition, number of meetings). According to data for family owned firms in Europe, they tend to invest less in R\&D because those investments usually involve high risk and a long payback period, which a family owned business in not always willing to undertake. On the other hand, larger firms usually apply more R\&D and open innovation, although those results are not consistent among countries and different types of ownership [44].

Furthermore, when managers are holding shares of the firm, they tend to follow strategies which maximize shareholders profit such as R\&D and innovation [105]. Core and Guay [106] concluded that firms which provide varying incentive grants and also apply new equality grants and stock-based compensation manage to keep CEOs' motivation level high. So, firms acting under such an approach to keep managers incentives high, could motivate them to promote R\&D and open innovation ideas which further increase shareholders profits. In a study examining managers' compensation and firm corporate social responsibility, it is found that CEOs implement corporate social responsibility projects regardless of their pay sensitivity but in order to increase a firm's stock price [107].

Concerning the firm industry, product market and competition, it is found that firms belonging to industries where the competition is high should have less benefits from applying governance systems, while firms in non-competitive industries should benefit more as there is lower pressure on managers [108]. The increased importance of corporate governance towards environmental innovation within low competition industries is also supported by other researchers as well [45]. Thus, we expect that corporate governance systems could have a crucial role towards promoting R\&D and open innovation in markets where the competition is low. In our dataset, although we included the variable of firm industry, this variable was omitted, signifying a possible similarity in the competition force within the industries we examined. 
The role of open innovation should not be neglected as well. That is because open innovation can be a core driver for environmental innovation $[8,78]$, as it already became obvious from the literature analysis. Open innovation may provide all the needed knowledge from firms' external environment to their internal environment, in order to support their environmental innovations. The support of open innovation becomes critical as it is very difficult for firms to rely solely on their own resources to meet the environmental goals due to the need for novel processes and technologies [109].

The need for open innovation becomes more evident when firms must address the compliance with the environmental regulations, the need for novel technology, the customers' needs, the need for effective communication with external stakeholders and the need for new knowledge [110]. Taking into account the possible barriers for firms to be environmentally innovative, open innovation will make it easier for them to support and integrate environmental innovation into their strategies in a sustainable way [111].

Thus, a main motivation for firms to adopt open innovation is the fact that it is difficult for them to afford to innovate on their own [112]. Another motivation which is highly reported is the belief of many managers that open innovation is positively correlated with firm growth. Furthermore, the satisfaction of customers' needs, the acquisition of new knowledge, the development of complementary financial resources and the reduction of both the risk and the costs are also reported as important motivations for open innovation $[112,113]$.

However, in order for a firm to benefit from open innovation or open environmental innovation, it is necessary to change effectively its innovation models. More specifically, the traditional models of innovation require firms to generate and develop their own ideas by supporting them on their own [112]. The implementation of open innovation requires radical changes in these traditional models. First, open innovation requires a cognitive model to evaluate and analyze all the decisions about innovation. Second, firms should overcome inertia problems in the way for external knowledge and technology adoption, which refers to the so-called "not-invented-here syndrome". Third, new methods of procedures evaluation and performance measurement should be developed in order to monitor effectively the process of open innovation. Last, the innovating firms should take all the needed organizational change initiatives to proactively understand the changes in their business environment $[114,115]$.

The above-mentioned radical changes should be effectively supported by the firms' culture. Thus, culture is recognized as a very important factor for the success of open innovation implementation [116,117]. That is because a firm's culture is crucial in overcoming barriers in the way for open innovation, such as the not-invented-here syndrome, the aversion to risk or organizational inertia $[116,117]$. The characteristics of a firm's culture to overcome the abovementioned barriers include vision, knowledge, inspiration, leadership, creativity and the willingness to take risks $[116,118]$. In this framework, the role of corporate governance is determined to be very important as well [45].

If open innovation is implemented effectively, its dynamics may lead to the significant growth of a firm. As identified in the relevant literature, even a small firm may transform into a world leader if the open innovation dynamics are used effectively [119]. In such a relevant case, the open innovation dynamics that led a small firm to become a large one with a worldwide presence, include the expansion of dynamic feedback loops such as platforms that reestablish missing connections between firms and their environment, the expansion of open innovation culture and the expansion of open innovation costs during its growth process [119].

It should be noted here, that open innovation may not only change a firm, but an economy as well. More specifically, open innovation can lead to economic growth as it can support the development of entrepreneurial technology and markets through the generation of new start-ups and SMEs [120]. The modeling of modern economy under the prism of open innovation can be further explained based on three sub-economies which include: market open innovation (which is connected with start-ups and SMEs), closed open innovation (which is connected with large firms) and social open innovation [120]. The low balance between these sub-economies (when any of the sub-economies is too developed or 
too underdeveloped) leads to a slowdown of the economy's growth rate, while a medium balance (when any of the sub-economies is developed enough to lead the economy but not so developed to manipulate the other two sub-economies) leads to maintaining the economy's high growth rate. Last, a high balance between the three sub-economies leads in a low level of economic growth rate [120].

However, open innovation and especially open environmental innovation may not just have an impact only on firms or on the economy. The dynamics of open innovation and open environmental innovation are critical for society as well [121]. That is because in the contemporary period that we live in and is characterized by the climate change, natural disasters and emerging pandemics, open innovation and open environmental innovation play a key role in the way for developing a more sustainable future [116].

\section{Conclusions, Limitations and Future Research Directions}

\subsection{Conclusions}

The present study aimed to investigate the contribution of environmental innovation to firms' competitive advantage construct. Based on the relevant literature and the PCA carried out, two types of environmental innovation are identified: environmental process innovation and environmental product innovation.

The research results revealed a moderate level of environmental innovation. Concerning environmental process innovation, the most implemented practice is this of ISO certifications. This reflects the importance managers pay to ISO certification and the positive effects they seek through it [122]. Another reason for this would be the fact that in many cases of business transactions, ISO certification is mandatory. On the other hand, natural environmental seminars for the firms' executives is the least implemented practice of environmental process innovation [122]. However, firms should pay environmental education more attention, as it is found to be connected with better implementation of the environmental strategy and improved firm performance [4].

As far as environmental product innovation is concerned, firms seem to take seriously into consideration the need for toxic substances usage reduction as it is the most implemented practice. On the contrary, in contrast to the country's energy mix $[5,123]$, the examined firms use energy from renewable sources at a moderate level. Last, the environmental product innovation practice, which is found to be the least implemented is that of environmental events sponsorship. Thus, there is evidence that managers do not seem to believe that sponsorships to environmental events would have a positive effect on the firms' performance; however, according to several researchers, such actions would significantly improve firms' reputation and customers' views on them [61]. The results of environmental innovation analysis confirm that Greek firms are trying to reach the level of other European countries $[8,124,125]$; however, there are still several actions to be taken.

Societies with high environmental awareness can reward environmentally innovative firms as such firms are considered to be agents of a better world. Therefore, a firm's compliance with environmental and cultural values of a society can be regarded as an essential institutional requirement to develop advanced and successful environmental management initiatives. However, all environmentally innovative firms cannot have the necessary conditions to obtain the performance improvements of environmental innovation. In this respect the need of adhering to a cross-industry innovation process can be stressed, which refers to an increasing awareness of corporate venturing activities, new business models, such as new ventures and spin-offs and the commercialization of own technologies in new markets [63]. Environmentally innovative firms that exhibit a high level of environmental innovation intensity can enhance their corporate financial performance.

Nevertheless, it has to be signified that while deploying cost leadership and product differentiation to improve firms' financial performance, it is not confirmed that environmental innovations are really driven by the existing regulations. Therefore, when a firm introduces both efficiency-improving innovations and any other type of environmental innovations, it is not clear which of these innovations 
is driven by the regulations [10]. In such a regulation-induced approach, firms should keep an open strategy for searching information sources and an open thinking for innovation paths [36].

Moreover, it can be stated that open innovation in firms can be effectively approached through methods that are actually conceptual models and dynamic systems applied (or should be applied) to the macroeconomic, collaborative economy, and electronic commerce fields all considering, more or less, some component of sustainability. Pursuing open innovation in firms through sustainability entails business development, co-creation, knowledge management, mitigation of climate change and environmental impact, ecosystems, decision-making, economics, life cycle and energy efficiency, which in turn represent promising topics for future research and achievement of industry objectives [126].

The results of the current research point out that firms that integrate environmental innovation into their strategy are likely to have a positive perspective for competitive advantage development. More specifically, the research results revealed a positive relationship between both the environmental process and the environmental product innovation and competitive advantage. This result is in agreement with the results of relevant studies from other countries as they record a positive relationship between environmental innovation constructs and competitive advantage as well [10,13,48-54,56,57]. Notably, the contribution of environmental innovation constructs to firms' competitive advantage is a high percentage of the total variance. This is the most critical finding of the current study to be highlighted as the importance of environmental innovation integration into contemporary firms' strategies is confirmed.

When examining environmental innovation, it is important to consider the application of corporate governance systems within the examined firm's sample. The use of corporate governance systems may be more beneficial for environmental innovation promotion in sectors with low competition $[45,108]$.

Finally, the CEO's incentives systems should be analyzed since providing equality grants and stock options to them can lead to a strategic planning towards the promotion of open innovation in order to increase the value of the company in the log-run [105-107].

\subsection{Limitations and Future Research Directions}

As already mentioned, there is no evidence of a double causal relationship. However, despite the results of the relevant studies we should note here that a two-sided interaction between environmental innovation and competitive advantage cannot be totally ruled out. This would mean that there is a chance for firms with competitive capability to be more likely to develop environmentally innovative products and processes. This is a potential constraint of this research that should be taken into consideration.

Concerning endogeneity, we did not obtain evidence supporting its existence. However, we have followed a simple way to address this issue. Moreover, as it is truly hard to find the sources of endogeneity in many cases [127], there are several remedies identified in the literature that could be used in a future research. Such remedies include instrumental variables, dynamic modelling, control variables, or the lagged dependent or independent variables [101]. It should be taken into consideration that firm size is identified by many relevant studies as a key variable affecting both the dependent variable and its predictors simultaneously. This does not happen in our research as we analyzed solely medium- and large-sized firms $[76,80]$ and is omitted from the model. Thus, in a future research where firms of all sizes will be examined, firm size should be taken into consideration as a variable of high importance that could possibly be related with the existence of endogeneity. Given the fact that most of the empirical papers face endogeneity issues [128], the search and remediation of it requires much more analysis. This analysis would even constitute a separate study.

Furthermore, the regression analysis carried out has some restrictions such as the prior knowledge of the relationships between the variables, the possible existence of multicollinearity problem and the assumption of linearity [129]. Artificial neural network, adaptive neuro-fuzzy inference systems [129] or panel data analysis [54] are some of the other methods identified in the relevant literature. 
These methods would be used in future research. A panel data analysis covering multiple points of time would provide significant evidence on the evolution of environmental innovation engagement to Greek firms and its contribution to their competitive capability.

Additionally, the research sample was limited. That is because we have used data concerning only medium and large-sized firms. The fact that these firms are only $1.1 \%$ of the total number of firms operating in Greece would explain the fact that firms' size or firms' industry are not found to be control variables of competitive advantage. However, the limitation of research sample it is not new. Such limitations are also reported in other relevant studies where it is shown that open innovation practices and environmental innovation performance of firms belonging to bio-economy, a sector with high strategic importance in the face of global climate change, are still scarce or even neglected [35].

Moreover, as already mentioned, the research results are based on the respondents' views. Thus, the objectivity of the results is not guaranteed. For example, it is possible for some of the respondents to hide the potential failure of their firms' investments in environmental innovation. This is a common limitation in relevant studies [74]. As far as it is concerned, future research could be based on firms' quantitative data, including the financial sheets and expenditures in environmental innovation. In this way, firms could be categorized based on their investments in R\&D and environmental innovation. Furthermore, it will become obvious if the sample consists solely of firms that benefit from environmental innovation or not, as it is critical to obtain data from both of them. Thus, the objectivity of the data would be strengthened.

In a future research, different types of environmental innovation can be examined, while the drivers of environmental innovation would be identified as well [10]. Such drivers would be investments in research and development, regulations, international competitiveness [130,131], customers' and stakeholders' pressures [1,3-5,39,131,132] or managers' environmental perceptions [38,62], or linking external technology acquisition with external technology exploitation in such a way that firms with greater external technology acquisition can obtain greater knowledge and, in turn, to strengthen their ability in adopting external technology exploitation [47].

The power of technological innovations to overcome resource availability and utilization shortcoming would be analyzed as well [13]. It is interestingly argued that the need for future researchers to accumulate additional experience and knowledge in engaging open innovation strategies, as that of emphasizing, or not, outbound open innovation effect on firm performance, since firms need to be aware of the boundary conditions under which the benefit of outbound open innovation is particularly significant $[35,47]$.

Conclusively it can be signified that:

- Firstly, open innovation is a heterogeneous phenomenon and it should be studied in a multidimensional approach. Although an ideal measure of firm performance does not exist, future researchers should explore different measures to study open innovation performance [47].

- Secondly, innovation measurement is always looking for an appropriate metrics system that monitors the investments and impact of open versus closed innovation approaches in order to support companies to find their right balance [63]. While open innovation focused on extending the firms' knowledge from external sources [36], innovation is following the routes of finding, developing and following up with internal R\&D [37]. It is argued that knowledge management is one of the most important factors affecting the level of innovation in knowledge-intensive organizations [36].

- Thirdly, management attention is considered among a firm's most important resources. Therefore, the misallocation of management attention can lead to either excessive or insufficient external and internal communication channels. As a result, policy-makers need to exert their efforts and to be focused on those issues related to sustainable strategic performance [36]. Under this recommendation, open innovation is not bounded on strict managerial routes followed by firms, but has strongly focused on wider domains of peer-production, through communities, consumers, lead users, universities or research organizations and partners from other industries [63]. 
- Fourthly, greater in-depth analysis should direct future researchers to investigate the effects of inbound and outbound open innovation practices and public policies on the performance of environmentally innovative firms [35].

Last, based on the model's adjusted $\mathrm{R}$ squared we obtain that $34.9 \%$ of the variance of firms' competitive advantage is explained by environmental innovation. This level is high taking into consideration that a firm's competitive advantage is a multifactorial concept. However, it can be signified that this level would be lower as it was based on an approach of competitive advantage using items that can be easier influenced by environmental innovation [53]. Thus, there are several variables that could be used in a future research's model. Such variables are identified in relevant studies including knowledge management, organizational capabilities, process management, customer focus, organizational culture [74], quality management practices [133] or investments in R\&D [134].

Author Contributions: M.S., S.N. and M.C. conceptualized the paper, designed the experimental framework and performed data analysis. M.S., G.L.K., G.A. and S.G. collected the research data, gathered and implemented all the theoretical background of the paper and discussed the results. All the authors have equally contributed in the paper's writing, reviewing and editing. All authors have read and agreed to the published version of the manuscript.

Funding: The research received no external funding.

Conflicts of Interest: The authors declare no conflict of interest.

\section{Appendix A}

Table A1. Environmental process innovation, environmental product innovation and competitive advantage constructs' items.

\begin{tabular}{|c|c|c|c|}
\hline \multirow[t]{2}{*}{ Items } & \multicolumn{3}{|c|}{ Components' Loadings } \\
\hline & A & B & $\mathrm{C}$ \\
\hline Natural environmental aspects in administrative work & 0.799 & & \\
\hline Periodic natural environmental audits & 0.657 & & \\
\hline Systematic program of water recycling & - & - & - \\
\hline Program of residue recycling & 0.711 & & \\
\hline Natural environmental seminars for executives & 0.731 & & \\
\hline Environmental training for employees & - & - & - \\
\hline Use of ISO certifications on quality and/or environmental aspects & 0.861 & & \\
\hline Insurance planning to cover potential environmental risks & - & - & - \\
\hline Procedures including precise instructions on environmental operations & 0.624 & & \\
\hline Filters and controls on emissions and discharges & - & - & - \\
\hline Sponsorship of natural environmental events & & & 0.546 \\
\hline Use of natural environmental arguments in marketing & & & 0.831 \\
\hline Purchasing criteria including ecological requirements & & & 0.732 \\
\hline Use of "Life Cycle Analysis" & & & 0.923 \\
\hline Reduction in the use of toxic substances & & & 0.760 \\
\hline Use of eco-friendly materials & & & 0.846 \\
\hline Improvement of efficiency in the use of materials & - & - & - \\
\hline Improvement of energy efficiency & & & 0.780 \\
\hline Use of energy from renewable sources & & & 0.636 \\
\hline Reduction of pollution & & & 0.646 \\
\hline Products' and services' image improvement & & 0.891 & \\
\hline Sales & & 0.828 & \\
\hline Market share & & 0.720 & \\
\hline New opportunities in the market & & 0.871 & \\
\hline Improving the corporate image & & 0.866 & \\
\hline Satisfaction of shareholders & & 0.751 & \\
\hline Satisfaction of managers & & 0.861 & \\
\hline Satisfaction of employees & & 0.885 & \\
\hline
\end{tabular}


Table A1. Cont.

\begin{tabular}{|c|c|c|c|}
\hline \multirow[t]{2}{*}{ Items } & \multicolumn{3}{|c|}{ Components' Loadings } \\
\hline & $\mathbf{A}$ & B & C \\
\hline Recruitment and retention of staff & \multicolumn{3}{|c|}{0.848} \\
\hline Higher short-term profits & \multicolumn{3}{|c|}{0.708} \\
\hline Higher long-term profits & \multicolumn{3}{|c|}{0.882} \\
\hline Higher cost reduction & \multicolumn{3}{|c|}{0.779} \\
\hline Increase productivity & \multicolumn{3}{|c|}{0.870} \\
\hline Improving insurance conditions & - & - & - \\
\hline Easier access to bank loans & - & - & - \\
\hline
\end{tabular}

A: refers to green process innovation component. B: refers to green product innovation component. C: refers to competitive advantage component.

Table A2. Kruskal-Wallis test $p$-values.

\begin{tabular}{cccc}
\hline & Chi-Square & df & Sig. \\
\hline Sponsorship of natural environmental events & 11.299 & 9 & 0.256 \\
Use of natural environmental arguments in marketing & 8.595 & 9 & 0.476 \\
Natural environmental aspects in administrative work & 7.733 & 9 & 0.561 \\
Periodic natural environmental audits & 10.299 & 9 & 0.327 \\
Systematic program of water recycling & 7.259 & 9 & 0.61 \\
Program of residue recycling & 9.243 & 9 & 0.415 \\
Purchasing criteria including ecological requirements & 11.387 & 9 & 0.25 \\
Natural environmental seminars for executives & 15.341 & 9 & 0.082 \\
Environmental training for employees & 18.554 & 9 & 0.029 \\
Use of ISO certifications on quality and/or environmental aspects & 14.926 & 9 & 0.093 \\
Insurance planning to cover potential environmental risks & 13.504 & 9 & 0.141 \\
Procedures including precise instructions on environmental operations & 12.394 & 9 & 0.192 \\
Filters and controls on emissions and discharges & 8.286 & 9 & 0.506 \\
Use of "Life cycle analysis" & 13.106 & 9 & 0.158 \\
Reduction in the use of toxic substances & 8.676 & 9 & 0.468 \\
Use of eco-friendly materials & 7.165 & 9 & 0.62 \\
Improvement of efficiency in the use of materials & 10.805 & 9 & 0.289 \\
Improvement of energy efficiency & 9.783 & 9 & 0.368 \\
\hline
\end{tabular}

Grouping variable: firms' industry.

\section{References}

1. Weng,H.H.R.; Chen, J.S.; Chen, P.C. Effects of Green Innovation on Environmental and Corporate Performance: A Stakeholder Perspective. Sustainability 2015, 7, 4997-5026. [CrossRef]

2. Papageorgiou, A.; Skordoulis, M.; Trichias, C.; Georgakellos, D.; Koniordos, M. Emissions trading scheme: Evidence from the European Union countries. In Communications in Computer and Information Science; Kravets, A., Shcherbakov, M., Kultsova, M., Shabalina, O., Eds.; Springer International Publishing: Cham, Switzerland, 2015; pp. 222-233.

3. Ntanos, S.; Kyriakopoulos, G.; Chalikias, M.; Arabatzis, G.; Skordoulis, M. Public perceptions and willingness to pay for renewable energy: A case study from Greece. Sustainability 2018, 10, 687. [CrossRef]

4. Ntanos, S.; Asonitou, S.; Kyriakopoulos, G.; Skordoulis, M.; Chalikias, M.; Arabatzis, G. Environmental sensitivity of business school students and their attitudes towards social and environmental accounting. In Strategic Innovative Marketing and Tourism; Kavoura, A., Kefallonitis, E., Theodoridis, P., Eds.; Springer: Cham, Switzerland, 2020; pp. 195-203.

5. Skordoulis, M.; Ntanos, S.; Arabatzis, G. Socioeconomic evaluation of green energy investments: Analyzing citizens' willingness to invest in photovoltaics in Greece. Int. J. Energy Sect. Manag. 2020, 14, 871-890. [CrossRef]

6. Ar, I.M. The impact of green product innovation on firm performance and competitive capability: The moderating role of managerial environmental concern. Procedia Soc. Behav. Sci. 2012, 62, 854-864. [CrossRef] 
7. Ma, Y.; Hou, G.; Xin, B. Green process innovation and innovation benefit: The mediating effect of firm image. Sustainability 2017, 9, 1778.

8. De Marchi, V.; Grandinetti, R. Knowledge strategies for environmental innovations: The case of Italian manufacturing firms. J. Knowl. Manag. 2013, 17, 569-582. [CrossRef]

9. Berrone, P.; Fosfuri, A.; Gelabert, L.; Gomez-Mejia, L.R. Necessity as the mother of 'green' inventions: Institutional pressures and environmental innovations. Strateg. Manag. J. 2013, 34, 891-909. [CrossRef]

10. Rexhäuser, S.; Rammer, C. Environmental innovations and firm profitability: Unmasking the Porter hypothesis. Environ. Resour. Econ. 2014, 57, 145-167. [CrossRef]

11. Palmer, K.; Oates, W.E.; Portney, P.R. Tightening environmental standards: The benefit-cost or the no-cost paradigm? J. Econ. Perspect. 1995, 9, 119-132. [CrossRef]

12. Eiadat, Y.; Kelly, A.; Roche, F.; Eyadat, H. Green and competitive? An empirical test of the mediating role of environmental innovation strategy. J. World Bus. 2008, 43, 131-145. [CrossRef]

13. Porter, M.; van der Linde, C. Toward a new conception of the environment: Competitiveness relationship. J. Econ. Perspect. 1995, 9, 97-118. [CrossRef]

14. Aguilera-Caracuel, J.; Ortiz-de-Mandojana, N. Green Innovation and Financial Performance: An Institutional Approach. Organ. Environ. 2013, 26, 365-385. [CrossRef]

15. Vardopoulos, I.; Falireas, S.; Konstantopoulos, I.; Kaliora, E.; Theodoropoulou, E. Sustainability assessment of the agri-environmental practices in Greece. Indicators' comparative study. Int. J. Agric. Res. Gov. Ecol. 2018, 14, 368-399. [CrossRef]

16. Markatou, M. Measuring "sustainable" innovation in Greece: A patent based analysis. J. Innov. Bus. Best Pract. 2012, 2012, 1-10. [CrossRef]

17. Markatou, M. Renewable energy technologies in Greece: A patent based approach. Int. J. Renew. Energy Res. 2012, 2, 718-722.

18. Heras-Saizarbitoria, I.; Arana, G.; Boiral, O. Exploring the dissemination of environmental certifications in high and low polluting industries. J. Clean. Prod. 2015, 89, 50-58. [CrossRef]

19. Kassolis, M.G. The diffusion of environmental management in Greece through rationalist approaches: Driver or product of globalization? J. Clean. Prod. 2007, 15, 1886-1893. [CrossRef]

20. Iliopoulou-Georgudaki, J.; Theodoropoulos, C.; Konstantinopoulos, P.; Georgoudaki, E. Sustainable tourism development including the enhancement of cultural heritage in the city of Nafpaktos-Western Greece. Int. J. Sustain. Dev. World Ecol. 2017, 24, 224-235. [CrossRef]

21. Triantafillidou, E.; Tsiaras, S. Exploring entrepreneurship, innovation and tourism development from a sustainable perspective: Evidence from Greece. J. Int. Bus. Entrep. Dev. 2018, 11, 53-64. [CrossRef]

22. Nikolaou, I.E.; Evangelinos, K.I. A SWOT analysis of environmental management practices in Greek Mining and Mineral Industry. Resour. Policy 2010, 35, 226-234. [CrossRef]

23. Sepetis, A.; Goula, A.; Stasinopoulos, V.; Kastanioti, C.; Stasinopoulos, D. The implementation of Voluntary Environmental Agreements and Sustainable Balanced Scorecard in the Health Care Region of Greece. Int. J. Biol. Biomed. 2020, 5, 1-10.

24. Svoronou, E.; Holden, A. Ecotourism as a tool for nature conservation: The role of WWF Greece in the Dadia-Lefkimi-Soufli Forest Reserve in Greece. J. Sustain. Tour. 2005, 13, 456-467. [CrossRef]

25. Choi, G.; Parsa, H.G.; Sigala, M.; Putrevu, S. Consumers' environmental concerns and behaviors in the lodging industry: A comparison between Greece and the United States. J. Qual. Assur. Hosp. Tour. 2009, 10, 93-112. [CrossRef]

26. Nanaki, E.A.; Koroneos, C.J. Comparative economic and environmental analysis of conventional, hybrid and electric vehicles-the case study of Greece. J. Clean. Prod. 2013, 53, 261-266. [CrossRef]

27. Korra, E.; Giotopoulos, I.; Tsakanikas, A. CSR Practices and SME Innovativeness in Greece. Entrep. Sustain. Dev. Goals (Contemp. Issues Entrep. Res.) 2018, 8, 119-132.

28. European Commission. Eco-Innovation in Greece: EIO Country Profile 2018-2019; Eco-Innovation Observatory: Bruxelles, Belgium, 2020.

29. Eurostat. Available online: https://ec.europa.eu/eurostat/tgm/table.do?tab=table\&init=1\&language=en\& pcode=t2020_rt200\&plugin=1 (accessed on 29 October 2020).

30. Halkos, G.; Sepetis, A. Can capital markets respond to environmental policy of firms? Evidence from Greece. Ecol. Econ. 2007, 63, 578-587. [CrossRef] 
31. European Commission. Eco-Innovate! A Guide to Eco-Innovation for SMEs and Business Coaches; Eco-Innovation Observatory: Bruxelles, Belgium, 2016.

32. Klemmer, P.; Lehr, U.; Löbbe, K. Environmental Innovation: Incentives and Barriers; German Ministry of Research and Technology: Berlin, Germany, 1999.

33. Chen, Y.S.; Lai, S.B.; Wen, C.T. The Influence of Green Innovation Performance on Corporate Advantage in Taiwan. J. Bus. Ethics 2006, 67, 331-339. [CrossRef]

34. Halila, F.; Rundquist, J. The development and market success of eco-innovations. Eur. J. Innov. Manag. 2011, 14, 278-302. [CrossRef]

35. Leitão, J.; Pereira, D.; Brito, S.D. Inbound and Outbound Practices of Open Innovation and Eco-Innovation: Contrasting Bioeconomy and Non-Bioeconomy Firms. J. Open Innov. Technol. Mark. Complex. 2020, 6, 145. [CrossRef]

36. Zhao, S.; Sun, Y.; Xu, X. Research on open innovation performance: A review. Inf. Technol. Manag. 2016, 17, 279-287. [CrossRef]

37. Monsef, S.; Wan Ismail, W.K. The Impact of Open Innovation in New Product Development Process. Int. J. Fundam. Psychol. Soc. Sci. 2012, 2, 7-12.

38. Banerjee, S.B. Managerial perceptions of corporate environmentalism: Interpretations from industry and strategic implications for organizations. J. Manag. Stud. 2001, 38, 489-513. [CrossRef]

39. Dolores Lopez-Gamero, M.; Claver-Cortés, E.; Francisco Molina-Azorin, J. Environmental perception, management, and competitive opportunity in Spanish hotels. Cornell Hosp. Q. 2011, 52, 480-500. [CrossRef]

40. Jaggi, B.; Zhao, R. Environmental performance and reporting: Perceptions of managers and accounting professionals in Hong Kong. Int. J. Account. 1996, 31, 333-346. [CrossRef]

41. Skordoulis, M.; Arabatzis, G.; Chalikias, M.; Ntanos, S.; Galatsidas, S.; Drosos, D. Managers' Perceptions on Environmental Sustainability. In Proceedings of the 9th International Conference on ICT in Agriculture, Food and Environment (HAICTA 2020), Thessaloniki, Greece, 24-27 September 2020; pp. 407-415.

42. OECD/ Eurostat. Oslo Manual 2018: Guidelines for Collecting, Reporting and Using Data on Innovation, 4th ed.; The Measurement of Scientific, Technological and Innovation Activities; OECD Publishing: Paris, France; Eurostat: Luxembourg, 2018.

43. Chang, C.H. The Influence of Corporate Environmental Ethics on Competitive Advantage: The Mediation Role of Green Innovation. J Bus. Ethics 2011, 104, 361-370. [CrossRef]

44. Asensio-López, D.; Cabeza-García, L.; González-Álvarez, N. Corporate governance and innovation: A theoretical review. Eur. J. Manag. Bus. Econ. 2019, 28, 266-284. [CrossRef]

45. Amore, M.D.; Bennedsen, M. Corporate governance and green innovation. J. Environ. Econ. Manag. 2016, 75, 54-72. [CrossRef]

46. Taylor, N.; Barker, K.; Simpson, M. Achieving 'sustainable business': A study of perceptions of environmental best practice by SMEs in South Yorkshire. Environ. Plan. C: Gov. Policy 2003, 21, 89-105. [CrossRef]

47. Hung, K.-P.; Chou, C. The impact of open innovation on firm performance: The moderating effects of internal R\&D and environmental turbulence. Technovation 2013, 33, 368-380.

48. Aragón-Correa, J.A. Strategic proactivity and firm approach to the natural environment. Acad. Manag. J. 1998, 41, 556-567. [CrossRef]

49. Banerjee, S.B.; Iyer, E.S.; Kashyap, R.K. Corporate Environmentalism: Antecedents and Influence of Industry Type. J. Mark. 2003, 67, 106-122. [CrossRef]

50. Theyel, G. Management practices for environmental innovation and Performance. Int. J. Oper. Prod. Manag. 2000, 20, 249-266. [CrossRef]

51. Chiou, T.Y.; Chan, H.K.; Lettice, F.; Chung, S.H. The influence of greening the suppliers and green innovation on environmental performance and competitive advantage in Taiwan. Transp. Res. E 2011, 47, 822-836. [CrossRef]

52. Liao, Z. Temporal cognition, environmental innovation, and the competitive advantage of enterprises. J. Clean. Prod. 2016, 135, 1045-1053. [CrossRef]

53. Wagner, M.; Schaltegger, S. The Effect of Corporate Environmental Strategy Choice and Environmental Performance on Competitiveness and Economic Performance: An Empirical Study of EU Manufacturing. Eur. Manag. J. 2004, 22, 557-572. [CrossRef]

54. Fousteris, A.E.; Didaskalou, E.A.; Tsogas, M.M.H.; Georgakellos, D.A. The environmental strategy of businesses as an option under recession in Greece. Sustainability 2018, 10, 4399. [CrossRef] 
55. Aragón-Correa, J.A.; Sharma, S. A Contingent Resource-Based View of Proactive Corporate Environmental Strategy. Acad. Manag. Rev. 2003, 28, 71-88. [CrossRef]

56. Dangelico, R.M.; Pontrandolfo, P. Being 'Green and Competitive': The Impact of Environmental Actions and Collaborations on Firm Performance. Bus. Strategy Environ. 2015, 24, 413-430. [CrossRef]

57. Skordoulis, M.; Chalikias, M.; Galatsidas, S.; Arabatzis, G. Competitive Advantage Establishment through Sustainable Environmental Management and Green Entrepreneurship: A Proposed Differential Equations Framework. In Springer Earth System Sciences; Theodoridis, A., Ragkos, A., Salampasis, M., Eds.; Springer: Cham, Switzerland, 2019; pp. 205-219.

58. Koo, C.; Chung, N.; Ryoo, S.Y. How does ecological responsibility affect manufacturing firms' environmental and economic performance? Total Qual. Manag. Bus. Excell. 2014, 25, 1171-1189. [CrossRef]

59. Aldieri, L.; Vinci, C.P. Climate change and knowledge spillovers for cleaner production: New insights. J. Clean. Prod. 2020, 271, 122729. [CrossRef]

60. Aragón-Correa, J.A.; Hurtado-Torres, N.; Sharma, S.; García-Morales, V.J. Environmental strategy and performance in small firms: A resource-based perspective. J. Environ. Manag. 2008, 86, 88-103. [CrossRef] [PubMed]

61. Ntanos, A.; Skordoulis, M.; Ntanos, S. Millennial consumers' perceptions on the organic products. In Proceedings of the International Scientific Conference eRA-9, Piraeus, Greece, 2-24 September 2014; pp. 26-35.

62. Albertini, E. Does environmental management improve financial performance? A meta-analytical review. Organ. Environ. 2013, 26, 431-457. [CrossRef]

63. Enkel, E.; Gassmann, O.; Chesbrough, H. Open R\&D and open innovation: Exploring the phenomenon. RD Manag. 2009, 39, 311-316.

64. Aravossis, K.G.; Kapsalis, V.C.; Kyriakopoulos, G.L.; Xouleis, T.G. Development of a holistic assessment framework for industrial organizations. Sustainability 2019, 11, 3946. [CrossRef]

65. Kyriakopoulos, G.L.; Kapsalis, V.C.; Aravossis, K.G.; Zamparas, M.; Mitsikas, A. Evaluating circular economy under a multi-parametric approach: A technological review. Sustainability 2019, 11, 6139. [CrossRef]

66. Yu, W.; Ramanathan, R.; Nath, P. Environmental pressures and performance: An analysis of the roles of environmental innovation strategy and marketing capability. Technol. Soc. Chang. 2017, 117, 160-169. [CrossRef]

67. Sharma, S. Managerial interpretations and organizational context as predictors of corporate choice of environmental strategy. Acad. Manag. J. 2000, 43, 681-697.

68. European Commission. Available online: https://op.europa.eu/en/publication-detail/-/publication/79c0ce87f4dc-11e6-8a35-01aa75ed71a1/language-el/format-PDF (accessed on 1 July 2020).

69. Hellastat. Available online: https://imentor.ibhs.gr/home.do (accessed on 5 June 2020).

70. Chen, Y.S. The Driver of Green Innovation and Green Image-Green Core Competence. J. Bus. Ethics 2008, 81, 531-543. [CrossRef]

71. Eurostat/ European Commission. Environmental Pressure of Sectors, by NACE Code; Bio Intelligence Service: Paris, France, 2010.

72. Hellenic Statistical Authority. Available online: https://www.statistics.gr/en/home/ (accessed on 5 September 2020).

73. Dillman, D.A.; Smyth, J.D.; Christian, L.M. Internet, Phone, Mail, and Mixed-Mode Surveys: The Tailored Design Method; John Wiley \& Sons: Hoboken, NJ, USA, 2014.

74. Kafetzopoulos, D.; Gotzamani, K.; Gkana, V. Relationship between quality management, innovation and competitiveness. Evidence from Greek companies. J. Manuf. Technol. Manag. 2015, 26, 1177-1200. [CrossRef]

75. Ryszko, A. Proactive environmental strategy, technological eco-innovation and firm performance-Case of Poland. Sustainability 2016, 8, 156. [CrossRef]

76. López-Gamero, M.D.; Molina-Azorín, J.F.; Claver-Cortés, E. The whole relationship between environmental variables and firm performance: Competitive advantage and firm resources as mediator variables. J. Environ. Manag. 2009, 90, 3110-3121. [CrossRef] [PubMed]

77. Küçükoğlu, M.T.; Pınar, R.İ. Positive influences of green innovation on company performance. Procedia Soc. Behav. Sci. 2015, 195, 1232-1237. [CrossRef]

78. De Marchi, V. Environmental innovation and R\&D cooperation: Empirical evidence from Spanish manufacturing firms. Res. Policy 2012, 41, 614-623.

79. Armstrong, J.S.; Overton, T.S. Estimating non-response bias in mail surveys. J. Mark. Res. 1977, 14, $396-402$. [CrossRef] 
80. Theriou, N.G.; Maditinos, D.; Theriou, G. Knowledge Management Enabler Factors and Firm Performance: An empirical research of the Greek medium and large firms. Eur. Res. Stud. J. 2011, 14, 97-134. [CrossRef]

81. Tsai, K.H.; Liao, Y.C. Sustainability strategy and eco-innovation: A moderation model. Bus. Strategy Environ. 2017, 26, 426-437. [CrossRef]

82. Horbach, J.; Rammer, C.; Rennings, K. Determinants of eco-innovations by type of environmental impact-The role of regulatory push/pull, technology push and market pull. Ecol. Econ. 2012, 78, 112-122. [CrossRef]

83. Horbach, J. Empirical determinants of eco-innovation in European countries using the community innovation survey. Environ. Innov. Soc. Transit. 2016, 19, 1-14. [CrossRef]

84. Eurostat. Available online: https://ec.europa.eu/eurostat/cache/metadata/en/inn_cis2_esms.htm (accessed on 28 October 2020).

85. Drosos, D.; Skordoulis, M.; Chalikias, M. Measuring the impact of customer satisfaction on business profitability: An empirical study. Int. J. Technol. Mark. 2019, 13, 143-155. [CrossRef]

86. Foss, N.J.; Knudsen, T. The Resource-Based Tangle: Towards a Sustainable Explanation of Competitive Advantage. Manag. Decis. Econ. 2003, 24, 291-307. [CrossRef]

87. Sigalas, C.; Pekka-Economou, V. Revisiting the Concept of Competitive Advantage: Problems and Fallacies Arising from its Conceptualization. J. Strategy Manag. 2013, 6, 61-80. [CrossRef]

88. Lankoski, L. Determinants of Environmental Profit; Helsinki University of Technology: Helsinki, Finland, 2000.

89. Moen, $\varnothing$. The relationship between firm size, competitive advantages and export performance revisited. Int. Small Bus. J. 1999, 18, 53-72. [CrossRef]

90. Fabrigar, L.R.; Wegener, D.T.; MacCallum, R.C.; Strahan, E.J. Evaluating the use of exploratory factor analysis in psychological research. Psychol. Methods 1999, 4, 272-299. [CrossRef]

91. Hair, J.F.; Anderson, R.E.; Tatham, R.L.; Black, W.C. Multivariate Data Analysis; Prentice Hall: Upper Saddle River, NJ, USA, 1998.

92. Sharma, A.; Paliwal, K.K.; Imoto, S.; Miyano, S. Principal component analysis using QR decomposition. Int. J. Mach. Learn. Cybern. 2013, 4, 679-683. [CrossRef]

93. Nunnally, J.C. Psychometric Theory; McGraw-Hill Education: New York, NY, USA, 1994.

94. Shibata, G.; Tse, D.; Vertinsky, I.; Wehrung, D. Do norms of decision-making styles, organizational design and management affect performance of Japanese firms? An exploratory study of medium and large firms. Manag. Decis. Econ. 1991, 12, 135-146. [CrossRef]

95. Papadogonas, T.A. The financial performance of large and small firms: Evidence from Greece. Int. J. Financ. Serv. Manag. 2007, 2, 14-20. [CrossRef]

96. Taylor, A.; Taylor, M. Factors influencing effective implementation of performance measurement systems in small and medium-sized enterprises and large firms: A perspective from Contingency Theory. Int. J. Prod. Res. 2014, 52, 847-866. [CrossRef]

97. Meyers, L.S.; Gamst, G.; Guarino, A.J. Applied Multivariate Research: Design and Interpretation; Sage Publications: London, UK, 2016.

98. Papies, D.; Ebbes, P.; Van Heerde, H.J. Addressing endogeneity in marketing models. In Advanced Methods for Modeling Markets; Leeflang, P., Wieringa, J., Bijmolt, T., Pauwels, K., Eds.; Springer: Cham, Switzerland, 2017; pp. 581-627.

99. Daryanto, A. EndoS: An SPSS macro to assess endogeneity. Quant. Methods Psychol. 2020, 16, 56-70. [CrossRef]

100. Sajons, G.B. Estimating the causal effect of measured endogenous variables: A tutorial on experimentally randomized instrumental variables. Leadersh. Q. 2020, 31, 101348. [CrossRef]

101. Li, F. Endogeneity in CEO power: A survey and experiment. Invest. Anal. J. 2016, 45, 149-162. [CrossRef]

102. Demirgüç-Kunt, A.; Maksimovic, V. Law, finance, and firm growth. J. Financ. 1998, 53, 2107-2137. [CrossRef]

103. Roberts, M.R.; Whited, T.M. Endogeneity in empirical corporate finance. Handb. Econ. Financ. 2013, 2, 493-572. [CrossRef]

104. Ebbes, P.; Papies, D.; Van Heerde, H.J. Dealing with Endogeneity: A Nontechnical Guide for Marketing Researchers. In Handbook of Market Research; Homburg, C., Klarmann, M., Vomberg, A., Eds.; Springer: Cham, Switzerland, 2016; pp. 1-37.

105. Latham, S.F.; Braun, M. Managerial risk, innovation, and organizational decline. J. Manag. 2009, 35, $258-281$. [CrossRef]

106. Core, J.E.; Guay, W.R. The Use of Equity Grants to Manage Optimal Equity Incentive Levels. J. Account. Econ. 1999, 28, 151-184. [CrossRef] 
107. Ikram, A.; Li, Z.F.; MacDonald, T. CEO Pay Sensitivity (Delta and Vega) and Corporate Social Responsibility. Sustainability 2020, 12, 7941. [CrossRef]

108. Giroud, X.; Mueller, H.M. Corporate Governance, Product Market Competition, and Equity Prices. J. Financ. 2011, 66, 563-600. [CrossRef]

109. Spena, T.R.; Di Paola, N. Moving beyond the tensions in open environmental innovation towards a holistic perspective. Bus. Strategy Environ. 2020, 29, 1961-1974. [CrossRef]

110. Yang, D.; Wang, A.X.; Zhou, K.Z.; Jiang, W. Environmental strategy, institutional force, and innovation capability: A managerial cognition perspective. J. Bus. Ethics 2019, 159, 1147-1161. [CrossRef]

111. Yang, J.Y.; Roh, T. Open for green innovation: From the perspective of green process and green consumer innovation. Sustainability 2019, 11, 3234. [CrossRef]

112. Van de Vrande, V.; De Jong, J.P.; Vanhaverbeke, W.; De Rochemont, M. Open innovation in SMEs: Trends, motives and management challenges. Technovation 2009, 29, 423-437. [CrossRef]

113. Mohr, J.; Spekman, R. Characteristics of partnership success: Partnership attributes, communication behavior, and conflict resolution techniques. Strateg. Manag. J. 1994, 15, 135-152. [CrossRef]

114. Chiaroni, D.; Chiesa, V.; Frattini, F. Unravelling the process from Closed to Open Innovation: Evidence from mature, asset-intensive industries. RD Manag. 2010, 40, 222-245. [CrossRef]

115. Chesbrough, H. Open Business Models: How to Thrive in the New Innovation Landscape; Harvard Business School Press: Boston, MA, USA, 2006.

116. Yun, J.J.; Zhao, X.; Jung, K.; Yigitcanlar, T. The culture for open innovation dynamics. Sustainability 2020, 12, 5076. [CrossRef]

117. Aquilani, B.; Abbate, T.; Codini, A. Overcoming cultural barriers in open innovation processes through intermediaries: A theoretical framework. Knowl. Manag. Res. Pract. 2017, 15, 447-459. [CrossRef]

118. Schumpeter, J. The Theory of Economic Development; Springer: Berlin/Heidelberg, Germany, 1934.

119. Yun, J.J.; Zhao, X.; Park, K.; Shi, L. Sustainability Condition of Open Innovation: Dynamic Growth of Alibaba from SME to Large Enterprise. Sustainability 2020, 12, 4379. [CrossRef]

120. Yun, J.J.; Won, D.; Park, K. Entrepreneurial cyclical dynamics of open innovation. J. Evol. Econ. 2018, 28, 1151-1174. [CrossRef]

121. Yigitcanlar, T.; DeSouza, K.C.; Butler, L.; Roozkhosh, F. Contributions and risks of artificial intelligence (AI) in building smarter cities: Insights from a systematic review of the literature. Energies 2020, 13, 1473. [CrossRef]

122. Drosos, D.; Skordoulis, M.; Chalikias, M.; Kalantonis, P.; Papagrigoriou, A. The Impact of ISO 9001 Quality Management System Implementation in Tourism SMEs. In Tourism, Culture and Heritage in a Smart Economy; Katsoni, V., Upadhya, A., Stratigea, A., Eds.; Springer: Cham, Switzerland, 2017; pp. 145-157.

123. Drosos, D.; Skordoulis, M.; Arabatzis, G.; Tsotsolas, N.; Galatsidas, S. Measuring industrial customer satisfaction: The case of the natural gas market in Greece. Sustainability 2019, 11, 1905. [CrossRef]

124. Wagner, M. On the relationship between environmental management, environmental innovation and patenting: Evidence from German manufacturing firms. Res. Policy 2007, 36, 1587-1602. [CrossRef]

125. Töbelmann, D.; Wendler, T. The impact of environmental innovation on carbon dioxide emissions. J. Clean. Prod. 2020, 244, 118787. [CrossRef]

126. Cano, J.-A.; Londono-Pineda, A. Scientific Literature Analysis on Sustainability with the Implication of Open Innovation. J. Open Innov. Technol. Mark. Complex. 2020, 6, 162. [CrossRef]

127. Chi, J. Understanding the endogeneity between firm value and shareholder rights. Financ. Manag. 2005, 34, 65-76. [CrossRef]

128. Chenhall, R.H.; Moers, F. The issue of endogeneity within theory-based, quantitative management accounting research. Eur. Account. Rev. 2007, 16, 173-196. [CrossRef]

129. Chen, Y.S.; Chang, K.C. The nonlinear effect of green innovation on the corporate competitive advantage. Qual. Quant. 2013, 47, 271-286. [CrossRef]

130. Brunnermeier, S.B.; Cohen, M.A. Determinants of environmental innovation in US manufacturing industries. J. Environ. Econ. Manag. 2003, 45, 278-293. [CrossRef]

131. Hojnik, J.; Ruzzier, M. What drives eco-innovation? A review of an emerging literature. Environ. Innov. Soc. Transit. 2016, 19, 31-41. [CrossRef]

132. Ntanos, S.; Kyriakopoulos, G.; Chalikias, M.; Arabatzis, G.; Skordoulis, M.; Galatsidas, S.; Drosos, D. A social assessment of the usage of renewable energy sources and its contribution to life quality: The case of an Attica urban area in Greece. Sustainability 2018, 10, 1414. [CrossRef] 
133. Chatzoglou, P.; Chatzoudes, D. The role of innovation in building competitive advantages: An empirical investigation. Eur. J. Innov. Manag. 2018, 21, 44-69. [CrossRef]

134. Kalantonis, P.; Schoina, S.; Missiakoulis, S.; Zopounidis, C. The Impact of the Disclosed R \& D Expenditure on the Value Relevance of the Accounting Information: Evidence from Greek Listed Firms. Mathematics 2020, 8,730 .

Publisher's Note: MDPI stays neutral with regard to jurisdictional claims in published maps and institutional affiliations.

(C) 2020 by the authors. Licensee MDPI, Basel, Switzerland. This article is an open access article distributed under the terms and conditions of the Creative Commons Attribution (CC BY) license (http://creativecommons.org/licenses/by/4.0/). 